Review

\title{
Single-Cell Sequencing: Biological Insight and Potential Clinical Implications in Pediatric Leukemia
}

\author{
Donát Alpár ${ }^{1,+}{ }^{\oplus}$, Bálint Egyed ${ }^{1,2,+} \mathbb{C}$, Csaba Bödör ${ }^{1}$ and Gábor T. Kovács ${ }^{2, *}$ \\ 1 HCEMM-SE Molecular Oncohematology Research Group, 1st Department of Pathology and Experimental \\ Cancer Research, Semmelweis University, H-1085 Budapest, Hungary; \\ alpar.donat@med.semmelweis-univ.hu (D.A.); egyed.balint@med.semmelweis-univ.hu (B.E.); \\ bodor.csaba1@med.semmelweis-univ.hu (C.B.) \\ 2 2nd Department of Pediatrics, Semmelweis University, H-1094 Budapest, Hungary \\ * Correspondence: kovacs.gabor1@med.semmelweis-univ.hu; Tel.: +36-1-459-1500 \\ + Donát Alpár and Bálint Egyed are joint first authors and contributed equally to this work.
}

check for updates

Citation: Alpár, D.; Egyed, B.; Bödör,

C.; Kovács, G.T. Single-Cell

Sequencing: Biological Insight and Potential Clinical Implications in Pediatric Leukemia. Cancers 2021, 13, 5658. https://doi.org/10.3390/ cancers 13225658

Academic Editor: Ronald de Krijger

Received: 9 October 2021

Accepted: 9 November 2021

Published: 12 November 2021

Publisher's Note: MDPI stays neutral with regard to jurisdictional claims in published maps and institutional affiliations.

Copyright: (C) 2021 by the authors Licensee MDPI, Basel, Switzerland. This article is an open access article distributed under the terms and conditions of the Creative Commons Attribution (CC BY) license (https:// creativecommons.org/licenses/by/ $4.0 /)$.
Simple Summary: Leukemia is the most common type of childhood malignancy. While the clinical management of pediatric acute leukemia, especially acute lymphoblastic leukemia, underwent a remarkable improvement during the past decades, a subset of the patients still experience relapse and succumb to their disease. Emergence or repositioning of targeted therapies aided by the comprehensive characterization of single leukemic cells using advanced sequencing approaches may provide novel opportunities for therapeutic intervention in these patients. In our review, we summarize the status quo of single-cell-sequencing studies in pediatric leukemia, provide an overview of the current landscape of targeted agents applicable in this disease group, and highlight options for ways single-cell sequencing could further support the decision making related to the clinical management of pediatric leukemia.

Abstract: Single-cell sequencing (SCS) provides high-resolution insight into the genomic, epigenomic, and transcriptomic landscape of oncohematological malignancies including pediatric leukemia, the most common type of childhood cancer. Besides broadening our biological understanding of cellular heterogeneity, sub-clonal architecture, and regulatory network of tumor cell populations, SCS can offer clinically relevant, detailed characterization of distinct compartments affected by leukemia and identify therapeutically exploitable vulnerabilities. In this review, we provide an overview of SCS studies focused on the high-resolution genomic and transcriptomic scrutiny of pediatric leukemia. Our aim is to investigate and summarize how different layers of single-cell omics approaches can expectedly support clinical decision making in the future. Although the clinical management of pediatric leukemia underwent a spectacular improvement during the past decades, resistant disease is a major cause of therapy failure. Currently, only a small proportion of childhood leukemia patients benefit from genomics-driven therapy, as $15-20 \%$ of them meet the indication criteria of on-label targeted agents, and their overall response rate falls in a relatively wide range (40-85\%). The indepth scrutiny of various cell populations influencing the development, progression, and treatment resistance of different disease subtypes can potentially uncover a wider range of driver mechanisms for innovative therapeutic interventions.

Keywords: single-cell sequencing; pediatric leukemia; cellular heterogeneity; evolutionary trajectory; targeted therapy

\section{Introduction}

Most cancers are of monoclonal origin and characterized by an unleashed proliferation of tumor cells harboring genomic, epigenomic, and transcriptomic alterations acquired in a stepwise manner or in a single catastrophic event [1-5]. Different clinical outcomes of 
patients diagnosed with the same type of cancer are largely attributed to interpatient molecular heterogeneity observed across the above mentioned molecular layers [6,7]. Indeed, recurrent aberrations identified during the past decades with karyotyping, fluorescence in situ hybridization, microarray, and other molecular methods provided a common basis for classifying patients into distinct biological and prognostic subgroups, with a subset of these cytogenetic and molecular categories also defining the most effective mode of therapeutic intervention [8-10].

Next-generation sequencing (NGS) has dramatically revolutionized the research and diagnostics of malignant disorders and massively expanded our knowledge of mechanisms underlying cancer evolution, including transformation, clonal expansion, adaptative selection, and treatment resistance of tumor cells [11,12]. Novel findings arising from large-scale NGS studies have led to the introduction of new disease subgroups with distinctive genomic and/or transcriptomic features and hence to the refinement of formerly established classification systems [13-15]. In addition, the combination of NGS with multi-region and longitudinal sampling strategies unraveled a previously underestimated level of intrapatient and intratumor heterogeneity, often coupled with complex subclonal architecture and clinically relevant temporal changes of cancer cell populations [16-18]. Initially, these traits and mechanisms were indirectly inferred from bulk sequencing data based on, for example, different abundance and non-ubiquitous distribution of detected genetic variants or from averaged gene expression profiles of tumor cells residing in distinct spatial localizations. While from a technical point of view, signals detected in bulk-sequencing experiments are typically more stable and less prone to variation, analysis of single cells representing the basic units of selection during cancer evolution is indispensable to the precise spatiotemporal dissection of mechanisms associated with the disease initiation as well as development, progression, and treatment resistance of various tumor cell populations [19].

Single-cell sequencing (SCS) has been providing an increasingly deep insight into the genetic composition, subclonal architecture, regulatory network, gene expression profile, and even proteome-level phenotype of a wide range of cancers [20]. The amount and density of biological information that can be generated in a single experiment by the latest large-scale SCS technologies vastly outcompete the yield of other more conventional single-cell methods, such as karyotyping, in situ hybridization, immunophenotyping, flow cytometry, or mass cytometry, commonly used for investigating blood cancers [21]. Moreover, recently emerging approaches providing multimodal NGS datasets at the single-cell level allow to investigate the interplay between different classes of biomolecules, eventually facilitating the combined analysis of cell types, cell states, development trajectories, and cellular functions in patient samples at diagnosis and upon treatment [22].

Due to the easy accessibility of non-adherent, single leukemic cells, oncohematological malignancies have commonly been pivotal in elucidating key biological mechanisms, thus fueling the progress of cancer research and facilitating the development of novel therapeutical modalities [23]. Not surprisingly, blood cancers are also among the entities most commonly analyzed in SCS studies, where generation of high-quality, single-cell suspensions is of key importance [24,25]. In line with this, leukemia samples as well as lymphoma cells circulating in the peripheral blood were the subjects in hematology-focused projects of early days [26,27], with acute myeloid leukemia (AML) being the most frequently published oncohematological entity [28]. To date, SCS datasets have been generated for a wide range of blood cancers, including chronic myeloid leukemia [29], myeloproliferative neoplasms [30,31], myelodysplastic syndrome/acute myeloid leukemia [21,27,31-46], acute lymphoblastic leukemia (ALL) [47-58], chronic lymphocytic leukemia [59-61], mantle cell lymphoma [61-63], follicular lymphoma [61,64-66], diffuse large B-cell lymphoma [61], multiple myeloma [26,67], Hodgkin lymphoma [68], Sezary syndrome [69], mycosis fungoides [70], Waldenström's macroglobulinemia [25], as well as other types of B- and T-cell lymphoma [71-73].

Several papers have recently been published on the status quo of single-cell technologies and on their applications in blood cancer research [20-22,24,25,28,74-76]. In this 
review, we specifically focus on pediatric leukemia with an aim to summarize how SCS studies shed light on the pathobiology of this disease group and discuss how different layers of single-cell omics approaches can expectedly support clinical decision making in the future.

\section{Genomic, Epigenomic, and Transcriptomic Background of Pediatric Leukemia}

ALL represents $80 \%$ of all pediatric leukemia cases and comprises over 30 established or provisional genetic subtypes, with a significant subset of those being uncovered by advanced genomic and transcriptomic studies $[13,14,57,77]$. Pediatric ALL develops in multiple steps, with the initiating genomic lesion emerging in utero, as demonstrated in major genetic subtypes of the disease (i) by the identification of identical chromosomal rearrangements/gene fusions in monozygotic, monochorionic twins concordant for leukemia; (ii) by detecting the founder aberration in healthy co-twins of patients with ALL; and (iii) by backtracking the primary driver lesion in neonatal blood spots of patients after diagnosis $[78,79]$. Secondary aberrations required for the clinically manifest leukemia likely emerge postnatally and generate a branching subclonal architecture in the malignant cell population [80-82]. During the clinical disease course, leukemic cells with treatmentresistant potential gain selective advantage, and on average, a higher number of genetic alterations can be observed at the time of relapse as compared with diagnosis [83,84]. Recent studies reported distinct signatures of known or therapy-induced novel mutational processes leading to hypermutation and to the acquisition of relapse-driving, drug resistance-associated genomic aberrations [85-88]. SCS will expectedly aid the dissection of these processes, which tend to remain active during disease evolution regardless of the rise and fall of specific mutations, eventually conferring repeated relapse in a subset of the patients. Epigenomic features, such as methylation patterns and chromatin modifications, provide further layers of interpatient heterogeneity, rendering almost every patient with unique ALL [89]. Characteristic methylation signatures largely matching the underlying genetic background have been identified and provided basis for DNA methylation-based subtype prediction classifiers, contributing to the clarification of cytogenetically undefined ALL patient groups and facilitating the identification of novel gene fusions [90]. Some studies suggested that DNA methylation-based biomarkers are not independent predictive markers of patient outcome [91], while the combined analysis of methylation, DNA-protein interaction, and gene expression in a recent study has uncovered relapse-specific superenhancers shared by a majority of patients [92], demonstrating the potential of integrative omic approaches. Large microarray and NGS-based transcriptomic studies identified novel subgroups of ALL patients previously not categorized by more conventional cytogenetic and molecular genetic methods. These include the Ph-like, ETV6-RUNX1-like, KMT2A-like, ZNF384-like, DUX4-rearranged, and MEF2D fusion-harboring subgroups, which have prognostic significance and/or are enriched for specific chromosomal translocations, mutations, tumor-suppressor gene deletions, kinase gene fusions, kinase pathway activation, or dysregulated lymphoid transcription factors, with some of these alterations also providing opportunities for targeted therapeutical intervention (Table 1) [13,57,93-97].

AML, constituting $15 \%$ of pediatric leukemia, is also a genetically heterogenous disease, and the genomic landscape observed in children is remarkably different from the repertoire and distribution of aberrations observed in adults [15]. Even within pediatric AML, the incidence of common chromosomal translocations follows an age-specific pattern with, for example, the KMT2A fusions vastly affecting infants, while the RUNX1-RUNX1T1 and especially the $C B F$ fusions being detectable in older children. Similarly, age-dependent differences are discernible in the prevalence of mutations. Characteristic alterations, such as DNMT3, NPM1, IDH1/2, RUNX1, and TP53 mutations prevalent in adult de-novo AML, occur with much lower prevalence in children, while the NRAS, KIT, KRAS, WT1, $C B L$, GATA2, ASXL2, SETD2, and some additional genes more commonly affect children [15]. Similar to ALL, the genomic landscape of pediatric AML can significantly change with disease progression, as demonstrated by studies investigating matching diagnosis- 
remission-relapse trio samples [98]. DNA methylation and miRNA expression profiles revealed specific signatures that correspond to genetic subgroups or are associated with progression-free and overall survival, potentially applicable for molecular stratification of patients [15].

Juvenile myelomonocytic leukemia (JMML), accounting for around $2 \%$ of pediatric leukemia, is driven by mutations in the RAS pathway genes, with additional alterations in JAK/STAT signaling and in epigenetic modifier genes contributing to the leukemogenesis. Dissimilar to other types of pediatric leukemia, branching subclonal architecture and the development of relapse from an ancestral clone were not reported to be typical in JMML. Analysis of matching bulk diagnostic and relapse samples suggested that mutations identified at diagnosis persisted till relapse, and all early alterations emerged in a single dominant clone, with acquisition of additional aberrations following a linear fashion. In terms of prognostic significance, the number of mutations instead of their type seem to have prognostic relevance, with higher mutation counts being associated with shorter event-free and overall survival [99].

Table 1. Genetic subgroups as indication criteria for small-molecule targeted agents and guide for patient stratification in pediatric acute leukemia.

\begin{tabular}{|c|c|c|}
\hline Genetic Subgroup & $\begin{array}{c}\text { Possible Small-Molecule Targeted Agent or } \\
\text { Risk Prediction }\end{array}$ & Refs \\
\hline \multicolumn{3}{|c|}{ ALL } \\
\hline $\mathrm{Ph}^{+}(B C R-A B L 1)$ & TKI, Aurora kinase (alisertib) & [100] \\
\hline TCF3-PBX1 & PI3Ki (idelalisib), considerable response to chemotherapy & [101] \\
\hline TCF3-HLF & therapy-resistant disease, BCL2i (venetoclax) & [102] \\
\hline$K M T 2 A$ rearrangement & $\begin{array}{l}\text { FLT3i (quizartinib), DOT1L-i (pinometostat), proteasome } \\
\text { inhibitor (bortezomib), HDACi } \pm \text { DNMTi } \\
\text { aHSCT when poor response to induction is detected }\end{array}$ & [103] \\
\hline $\begin{array}{l}\text { ETV6-RUNX1, ETV6-RUNX1-like, DUX4 } \\
\text { rearrangement (often coincide with ERG }{ }^{\mathrm{del}} \text { ) }\end{array}$ & $\begin{array}{c}\text { Excellent prognosis, reduced intensity treatment } \\
\text { may be considered }\end{array}$ & [57] \\
\hline MEF2D rearrangement & HDACi (panabinostat), proteasome inhibitor (bortezomib) & [96] \\
\hline ZNF384 rearrangement & FLT3i (sunitinib) & [104] \\
\hline NT5C2 alteration & Anticipate thiopurine resistance, often associated with relapse & [105] \\
\hline$C R E B B P$ alteration & Anticipate corticosteroid resistance & [106] \\
\hline Hypodiploid & BCL2i (venetoclax), aHSCT & [107] \\
\hline High hyperdiploid & Low-risk disease & [13] \\
\hline iAMP21 & High-risk disease & [108] \\
\hline $\mathrm{NOTCH}^{+}$ & PSEN1i ( $\gamma$-secretase complex inhibition), & {$[109]$} \\
\hline$I K Z F 1^{\text {plus }}$ & $\begin{array}{c}\text { in the presence of IKZF1 alteration, FAKi potentiates other } \\
\text { drugs' antitumor effect } \\
\text { High-risk disease (even with low MRD values) }\end{array}$ & [110] \\
\hline$M Y C$ rearrangement & Resistant disease course & [111] \\
\hline NUP214-ABL1 & TKI & [112] \\
\hline $\begin{array}{c}\text { oncogene activation (eg. TAL1, LYL1, LMO1, TLX1, } \\
\text { TLX3) by translocation with TCR genes }\end{array}$ & Varying, but substantial prognostic effect & {$[113]$} \\
\hline CDKN2A/CDKN2B deletions & CDK4/CDK6i (palbociclib), & [114] \\
\hline KMT2A-ENL & $\begin{array}{l}\text { Despite KMT2A rearrangement, the prognosis is not poor in } \\
\text { T-cell, ALL and aHSCT is generally avoidable }\end{array}$ & {$[115]$} \\
\hline \multicolumn{3}{|c|}{ Ph-like precursor B-cell ALL } \\
\hline ABL class (ABL1, ABL2, CSF1R, PDGFRA, PDGFRB) & Dasatinib & \\
\hline CRLF2 class (IGH-CRLF2, P2RY8-CRLF2, CRLF2 ${ }^{\mathrm{mut}}$ ) & USP9Xi, HDACi (givinostat) & \\
\hline JAK2/EPOR class (JAK2, EPOR, PAX5) & JAKi (ruxolitinib) & {$[116,117]$} \\
\hline Ras/MAPK class (NRAS, KRAS, PTPN11, NF1) & MEKi (trametinib) & \\
\hline $\begin{array}{c}\text { Rare kinase fusions (NTRK3, FGFR1, PTK2B, TYK2, } \\
\text { DGKH, LYN) }\end{array}$ & $\begin{array}{l}\text { NTRKi (larotrectinib, NTRK3), ALKi/ROS1i (crizotinib, } \\
\text { NTRK3), ponatinib (FGFR1), FAKi (PTK2B), TYK2i (TYK2) }\end{array}$ & \\
\hline IKZF1 alteration in Ph-like cases & Retinoid use potentiates TKIs' effect & \\
\hline
\end{tabular}


Table 1. Cont.

Genetic Subgroup

KMT2A rearrangement

NUP98 rearrangement

CBF-AML (inv(16): CBFB-MYH11, $\mathrm{t}(8 ; 21)$ : RUNX1-RUNX1T1)

FLT3 activating mutations

(a) FLT3-ITD + NPM1 ${ }^{\text {mut }}$ (usually without DNMT3 $A^{\text {mut }}$ in children)

(b) FLT3-ITD + WT1 ${ }^{\text {mut }}$ or NUP98- NSD1

IDH1/IDH2 mutations (rare in children)

HIF1A, BRE and CLEC7A expression levels
Possible Small-Molecule Targeted Agent or Risk Prediction

AML

DOT1Li (pinometostat)

CDK6i (palbociclib), BCL2i (navitoclax)

High-risk disease (need for aHSCT)

KITi (dasatinib)

Low-risk disease

FLT3i (midostaurin, crenolanib, gilteritinib, lestaurtinib, quizartinib, sorafenib)

Refs

$[119,120]$

The coincidence anticipates a favorable prognosis, outcomes are better than in FLT3-ITD ${ }^{\text {neg }}$ cases

Usually unsuccessful induction, dismal prognosis, need for aHSCT

IDHi (enasidenib, ivosidenib)

Drug resistance toward cytarabine, daunorubicin, and/or etoposide

Abbreviations: ALL, acute lymphoblastic leukemia; AML, acute myeloid leukemia; Ph, Philadelphia; TKI, tyrosine kinase inhibitor; aHSCT, allogeneic hematopoietic stem cell transplantation; MRD, minimal residual disease; ITD, internal tandem duplication.

\section{Pathobiology Uncovered by Single-Cell Analysis}

SCS studies performed in pediatric leukemia to date primarily investigated the subclonal architecture, clonal evolution, developmental state, transcriptional heterogeneity, immunophenotype, and immunomodulatory activity of leukemic blasts. The analyses focused on specific leukemia-propagating cell subsets or complete leukemic cell populations, occasionally also including the interrogation of additional immune cell compartments.

\subsection{Pediatric Acute Lymphoblastic Leukemia}

Gawad et al. analyzed the co-segregation of single nucleotide variants (SNVs), deletions, and immunoglobulin heavy chain (IGH) gene rearrangements in single leukemic cells of six patients with B-ALL (5/6 harboring ETV6-RUNX1 gene fusion) using microfluidicsbased targeted DNA resequencing [47]. With a thorough analytical approach, the authors quantified the allele dropout conferred by the limitations of the applied whole genome amplification method and determined a maximum level of allele dropout and a minimum number of mutations required to reconstruct the clonal structure in the analyzed diagnostic patient samples. Importantly, they demonstrated that it is not possible to resolve the cells in the samples into distinct clones based on the previously generated bulk allele frequency data alone, highlighting the importance of single-cell analysis. The study identified codominant clones in 5/6 patients, unveiled APOBEC-driven clone-specific cytosine mutagenic events that were preceded by the emergence of structural variants, and revealed clones arrested at different stages of B-cell development within the same patient. An updated version of the method, still relying on upfront bulk-sequencing data, was later described by Easton et al. [56].

Li et al. used SCS for dissecting the segregation of 14 SNVs in 56 cells isolated from the relapse sample of a patient diagnosed with Ph-like B-ALL, harboring PAX5-NOL4L gene fusion. They found that two PRPS2 gene mutations, which were previously detected with bulk NGS, were present in different subclones, demonstrating convergent evolution during disease progression [85].

De Bie et al. performed microfluidics-based, single-cell targeted DNA resequencing and droplet-based, single-cell RNA sequencing in four patients with T-ALL [55]. The authors analyzed on average 24 tumor-associated aberrations per patient and identified up to four leukemic cell clones in the diagnostic samples. Gene expression profiling uncovered a very limited heterogeneity across the T-ALL cells. Selected genomic aberrations were 
also screened in single $\mathrm{CD} 34^{+} \mathrm{CD} 38^{-}$multipotent progenitor cells and in bulk myeloid cell population isolated from the same patients at diagnosis and during remission. In some patients, mutations started to accumulate in the multipotent progenitor cells and were also detectable in the myeloid compartment, highlighting the importance of performing allogeneic instead of autologous stem cell transplantation in high-risk patients. Scrutiny of the acquisition order of mutations revealed early mutations mainly in genes of undetermined significance. Intermediate aberrations included T-cell receptor gene rearrangements, $C D K N 2 A / B$ deletions, and gene fusions, while NOTCH1 mutations proved to be late subclonal events, questioning the concept of NOTCH1-targeted therapies.

In another study, Alberti-Servera et al. analyzed SNVs and small indels in 25 samples of eight patients with T-ALL using a droplet-based DNA resequencing approach, covering 305 genomic regions in 110 genes [52]. Samples were collected at diagnosis, during chemotherapy, or at relapse. More than two NOTCH1 mutations acquired after the accumulation of disease initiating alterations were detected in half of the patients, with the major clone harboring one or two mutations and with other NOTCH1 variants being present in minor subclones. Parallel evolution was also observed in the NRAS and JAK1 genes. The study revealed a variable clonal response to corticosteroid treatment, demonstrated the capability of the technology to detect residual leukemic cells during treatment, and identified relapse driving clones at an early stage of the disease.

Caron et al. performed RNA sequencing in single leukemic cells of eight patients with ALL (6 B-ALL and 2 T-ALL) in order to scrutinize intrapatient transcriptional heterogeneity at diagnosis [54]. They observed an association between gene expression heterogeneity and the predicted developmental state of the leukemic cells, which showed inverse correlation with the expression of ribosomal protein genes, especially in patients with T-ALL and high-hyperdiploid B-ALL. In patients with ETV6/RUNX1-positive B-ALL, gene expression heterogeneity at cellular level proved to be linked to metabolic regulation, B-cell activation, and cell proliferation. The study also tried to match transcriptionally defined cell subsets with genetic alterations and identified a couple of large deletions and gains, which were associated with specific gene expression clusters. Due to the sparsity of data, enrichment of somatic SNV alleles in the transcriptional clusters did not reach statistical significance.

Witkowski et al. analyzed diagnostic, remission, and relapse samples of nine patients with B-ALL using droplet-based, single-cell RNA sequencing (scRNA-seq; 7 patients) and cellular indexing of transcriptomes and epitopes by sequencing (CITE-seq; 4 patients), with the latter approach allowing for the simultaneous interrogation of single-cell transcriptome and cell surface protein composition [49]. The authors demonstrated a significant remodeling of the non-malignant bone marrow microenvironment prior to chemotherapy and unveiled a non-classical monocyte subpopulation, which gained selective advantage within the myeloid compartment at diagnosis and relapse. Importantly, increased monocyte abundance at diagnosis proved to be predictive of inferior clinical outcome in patients with B-ALL. The leukemia enhanced the non-classical monocyte differentiation, while monocyte-targeted therapy via CSFR1 receptor blockade conferred depletion of monocytes and increased sensitivity of B-ALL blasts to tyrosine kinase inhibitor (TKI) therapy in vivo.

Wu et al. re-analyzed the scRNA-seq data generated by Witkowski et al. and integrated it with a large bulk RNA-seq dataset in order to further characterize cell-cell interactions in B-ALL-associated bone marrow microenvironment [50]. They identified significantly up- or downregulated ligand-receptor pairs in the autocrine network of B cells and in the paracrine network of B and myeloid cells, with a subset of altered ligand-receptor pairs being associated with clinical outcome. Building upon these findings, the authors established a score-based model that seemed to support prognostic predictions within and also beyond B-ALL.

Mehtonen et al. used scRNA-seq for investigating cell states and transcription factor activities during normal B-cell differentiation and compared those to leukemic cell profiles of six patients with ETV6/RUNX1 B-ALL at diagnosis and during induction therapy (day 15) [58]. Their results suggested that ETV6/RUNX1-positive leukemic cell states 
are most similar to a pro-B state, differ between patients in cell cycle activity, express genes that reprogram the immune microenvironment, and that the induction therapy may modulate leukemic cells towards a pre-B state. Furthermore, the authors demonstrated the feasibility of monitoring the early treatment response using SCS and revealed elevated activity of specific transcription factors, e.g., ETS factors (ELK3, ERG, and FLI1), that could serve as targets for therapeutical intervention.

Anand et al. investigated patient-derived xenograft (PDX) models generated from diagnostic or relapse samples of pediatric patients with early T-cell progenitor (ETP) ALL or T-ALL using the Smart-Seq2 protocol allowing for full-length scRNA-seq analysis [53]. The authors also analyzed PDX and primary samples from adult patients and identified faster and slower cycling, stem-like cell populations in patients carrying NOTCH1 mutations. Fastcycling, stem-like cells showed high NOTCH activation, while the slow-cycling ones proved to be dependent on PI3K signaling and independent of NOTCH activation, explaining the low success rate that can be achieved by NOTCH inhibition in this entity. The study also demonstrated that cells with PI3K activity already exist at diagnosis, and the PI3K activation is independent of genetic mutations in the PI3K/AKT / PTEN genes, suggesting epigenetic rewiring as an underlying reason. In addition, the study shed light on the mode of immunomodulatory activity of leukemic cells, conferring CD8 ${ }^{+}$T-cell dysfunction via HAVCR2-LGALS9 interactions that could therapeutically be exploited in the future.

Candelli et al. analyzed a previously identified prednisone-dependent gene expression signature in 15 infants with MLL-rearranged B-ALL using plate-based and droplet-based scRNA-seq methods [124]. They demonstrated that classification of individual cells into resistant or sensitive groups, followed by the relative quantification of the two groups of cells may facilitate the prediction of an impending relapse. Characterization of treatmentresistant cells unveiled a quiescent nature with stemness features and elevated glucocorticoid response. Since the abundance of resistance signature widely correlated with clinical outcome across the patients, the authors concluded that the signature is rather generally associated with resistance to chemotherapy and likely not specific to prednisone.

\subsection{Pediatric Acute Myeloid Leukemia}

Despite the pioneering role of AML in early SCS studies, data generated from pediatric patients are still very limited. Walter et al. performed exome sequencing on five CD $34^{+} \mathrm{CD} 38^{-}$blasts from three patients diagnosed with pediatric AML [38]. Two cells had to be excluded from the downstream analysis due to the lack of sequencing coverage across the vast majority of the targeted regions. SCS results were compared to exome and targeted amplicon sequencing data generated on bulk DNA samples. In this technical paper, the authors concluded that two-thirds of the real, non-artefact somatic alterations determined as being observable with all three methods could be detected by single-cell whole exome sequencing (WES).

Demaree et al. simultaneously interrogated the genotype and immunophenotype of single blast cells in longitudinally collected samples of three patients with AML using DNA and Antibody sequencing (DAb-seq), with one patient representing pediatric AML [36]. By analyzing 49 DNA loci via targeted amplification and 23 protein markers with barcoded antibodies, the authors identified various proteogenomic patterns among the three patients. The pediatric patient harbored $M L L$ rearrangement and relapsed at month 10 after induction and consolidation therapies. In this patient, mutually exclusive KRAS G13D and FLT3 D835Y mutations were detected, with the latter one gaining selective advantage during disease progression. By investigating pathogenic blasts across all time points, immunophenotypic heterogeneity coupled with common genetic makeup as well as genetic diversity across blasts displaying shared malignant immunophenotype were observed, demonstrating that neither of the two layers of biological information would have been sufficient on their own to comprehensively characterize clinically relevant features in leukemic cells. 
Louka et al. investigated hematopoietic stem/progenitor cells from three patients diagnosed with JMML using scRNA-seq and/or single-cell DNA sequencing (scDNA-seq), with one patient being analyzed by both methods [37]. Transcriptome analysis revealed heterogeneous aberrant phenotype with myeloid bias and distinct molecular signature as compared with matching normal control cells isolated from cord blood. Up-regulated genes included myeloid as well as stem cell and fetal genes, proliferation markers, erythroid differentiation-associated genes, and potential therapeutical targets, such as MTOR and SLC2A1. Single-cell genotyping demonstrated that driver aberrations can be backtracked to the hematopoietic stem cell compartment, which showed a high level of clonal dominance and contained a small number of wild-type cells. Emergence of aberrations created linear and branching clonal evolutionary patterns, with RAS-pathway mutations being detected as the earliest alterations.

The studies briefly summarized above and listed in Table 2 demonstrate the power and versatile applicability of SCS to scrutinize pediatric leukemia blast populations as well as various immune cell subsets in the same sample at the genome, transcriptome, and proteome levels, eventually providing a highly granular profiling of intrinsic features and microenvironmental interactions that contribute to the development, progression, and treatment resistance of pediatric leukemia.

Table 2. Single-cell sequencing studies on primary samples of patients with pediatric leukemia.

\begin{tabular}{|c|c|c|c|c|c|c|}
\hline First Author & Year & Entity & $\begin{array}{l}\text { Number of } \\
\text { Patients } 1\end{array}$ & $\begin{array}{c}\text { Number of Cells } \\
\text { Analyzed }\end{array}$ & Method & Refs \\
\hline Gawad et al. & 2014 & B-ALL & 6 & 1479 & scDNA-seq & {$[47]$} \\
\hline Easton et al. & 2017 & ALL & 1 & 128 & scDNA-seq & [56] \\
\hline Walter et al. & 2017 & AML & 3 & 3 & scDNA-seq (WES) & [38] \\
\hline De Bie et al. & 2018 & T-ALL & 4 & 1507 and 8297 & scDNA-seq and scRNA-seq & [55] \\
\hline Li et al. & 2020 & B-ALL & 1 & 56 & scDNA-seq & [85] \\
\hline Caron et al. & 2020 & T-ALL & 8 & 39,375 & scRNA-seq & [54] \\
\hline Mehtonen et al. & 2020 & B-ALL & 6 & 44,746 & scRNA-seq & {$[58]$} \\
\hline Witkowski et al. & 2020 & B-ALL & 9 & 34,407 and 42,621 & scRNA-seq and CITE-seq & [49] \\
\hline Wu et al. ${ }^{2}$ & 2021 & B-ALL & 7 & 38,860 & scRNA-seq & {$[50]$} \\
\hline Alberti-Servera et al. & 2021 & T-ALL & 8 & 108,188 & scDNA-seq & [52] \\
\hline Demaree et al. & 2021 & AML & 1 & 14,465 & DAb-seq & [36] \\
\hline Candelli et al. & 2021 & B-ALL & 15 & 30,909 & scRNA-seq & [124] \\
\hline Louka et al. & 2021 & JMML & 3 & 645 and 17,547 & scDNA-seq and scRNA-seq & [37] \\
\hline
\end{tabular}

Footnotes: ${ }^{1}$ Pediatric patients are indicated. ${ }^{2}$ Partial re-analysis of the dataset generated by Witkowski et al. Abbreviations: ALL, acute lymphoblastic leukemia; AML, acute myeloid leukemia; scDNAseq, single-cell DNA sequencing; scRNAseq, single-cell RNA sequencing; WES, whole exome sequencing; CITE-seq, cellular indexing of transcriptomes and epitopes by sequencing; DAb-seq, DNA and Antibody sequencing.

\section{Clinical Aspects of Blast-Level Pathobiological Data}

Pharmaceutical research in oncotherapy had to keep pace with the rapid advancement of data generation facilitated by the accelerated development of molecular methods during the past decade. Translation of the enormously growing data, related to acute leukemia (AL) pathobiology, to a certain patient frequently needs data-mining approaches [56,125]. Main questions for the clinical practice of modern pediatric hematology as a response to novel genomic, epigenomic, and transcriptomic findings are as follows: (i) how can we better stratify patients and optimize treatment according to risk of relapse or refractory disease course; (ii) which clonal or subclonal alterations can allow for the administration of on- or off-label small-molecule targeted agents; and (iii) how can we therapeutically benefit from the monitoring of treatment-associated dynamic changes in the genomic and transcriptomic profiles? Besides providing valuable information, single-cell analysis generates additional challenging questions, mainly related to the integration of intra-patient heterogeneity of leukemic cells into clinical decision-making systems. Importantly, this requires an a priori extraction of clinically relevant heterogeneity from the biological heterogeneity uncovered by advanced molecular methods. 
In $\mathrm{AL}$, the predisposing germline genetic material, the repertoire of abundant mutations of de novo disease and that of relapsed leukemia are significantly different; hence, the biological behavior and treatment responsiveness of AL in patients may show substantial changes over time $[83,85,98]$. Clonal mutations in relapsed leukemia are often traceable back to subclones prevailing during the de novo disease period. Recent literature reports clinically relevant information about the temporal dynamics of mutations associated with relapse. First, relapse-fated minor clones already exhibiting resistance to first-line chemotherapy are often present at the time of diagnosis [126]. In a study by Waanders et al., genomic variants in relapse-driver genes, such as CREBBP, IKZF1, and NT5C2, were rarely lost if present at diagnosis or in early therapy phase of ALL. Therefore, early detection of these alterations, which requires minimal residual disease (MRD)-level targeted screening, may predict an increased probability of treatment failure and may provide a rationale for therapy intensification or novel drug approaches before further evolution of leukemia towards relapse [86]. Ediriwickrema et al. assessed MRD in patients with relapsed AML using single-cell and bulk NGS methods. Using SCS, they identified persistent mutations in $40-50 \%$ higher number of cases, further demonstrating the potential advantage of this approach [40]. Second, putative secondary AL evolution, even in patients with lineage shift, is usually not a second independent event but represents disease recurrence arising from an ancestral pre-leukemic clone of primary leukemia [86]. From a therapeutic point of view, "real secondary AL" should be separated from "genuine relapse". Secondary AL does not occur due to the low intensity of therapy but can be induced by mutagenic effect of overtreatment. Hence, patients in these cases face a new disease rather than a refractory leukemia course, which directs the clinician towards the application of standard frontline chemotherapy instead of following a more intensive relapse guideline. Nevertheless, allogeneic hematopoietic stem cell transplantation (aHSCT) should also be taken into account in case of "real secondary AL" to replace the predisposed leukemia stem cells [127]. Differential identification of second leukemia and relapse consists of immunoglobulin or T-cell receptor and/or fusion-gene-based clonality testing as well as cytogenetic and immunophenotypic examinations. This laborious and rather time-consuming workflow could be streamlined or at least greatly supported by properly designed SCS. Third, differential diagnosis of primary leukemia relapse and donor cell leukemia (DCL) after aHSCT may be challenging from both clinical and analytical points of view. We have previously reported a male patient with $B C R-A B L 1$-fusion-positive ALL, whose numerical sex chromosome aberrations and loss of chromosome $Y$ resulted from late clonal evolution caused difficulties in the interpretation of chimerism analysis at the time of relapse, after sex-mismatched aHSCT [128]. Without applying a combination of various techniques, the phenomenon could have been misdiagnosed as DCL. Since single-nucleotide polymorphism (SNP) genotyping is also feasible with SCS, this novel method could replace more conventional short tandem repeat (STR) analyses or complement sex-chromosome-based chimerism assessment after aHSCT and facilitate the detection of leukemia with or without donor cell origin.

Targeted immunotherapy is an emerging therapeutic option to achieve remission or constitute a bridge to aHSCT in childhood ALL. Currently, we are not aware of all the factors determining the clinical efficacy of boosting the anti-leukemia immune activity of own or donor immune cells. The thorough cell-level examination of tumor and immune cell clonality by SCS can identify new predictive biomarkers for immunotherapy. Rabilloud et al. used scRNA-seq to identify a relapse-driving CD19- subclone allowing ALL cells to evade CD19-targeted donor chimeric antigen receptor T-cell (CAR-T) therapy in a patient [129]. In another study, response rate to bispecific antibody blinatumomab seemed to depend on the patients' T-cell maturation state and clonality, as determined in SCS experiments using adult B-ALL samples [130]. These early results may pave the way for developing sequencing-based biomarkers associated with immunotherapy effectiveness in ALL.

Putative genomics-based stratification criteria in childhood AL expand in a rapid manner, in parallel with deeper genomic-transcriptomic characterization of real-world 
patient cohorts. Recent data on genetic subgroups as well as on prognostic significance of alterations and/or potentially applicable targeted therapies are summarized in Table 1. In pediatric ALL, favorable prognostic genetic events include ETV6-RUNX1 fusion, ETV6RUNX1-like expression pattern, DUX4 rearrangement, and high hyperdiploid karyotype, while $B C R-A B L 1$ fusion, intrachromosomal amplification of chromosome 21 (iAMP21), $I K Z F 1^{\text {plus }}$ copy number profile, and TCF3-HLF fusion are associated with inferior outcomes $[131,132]$. Certain alterations were found to be associated with resistance against backbone cytoreductive agents in ALL protocols (e.g., CREBBP aberrations predict corticosteroid resistance [106], while some studies suggested that NT5C2 alterations may predispose to poor response to 6-mercaptopurine [105]). In pediatric AML, NUP98 rearrangement, special activating alteration of FLT3 (internal tandem duplication, ITD), and WT1 mutations confer poor prognosis and drive the clinician towards aHSCT. DNMT3A mutations, representing early clonal events in adult AML, are associated with decreased sensitivity to anthracyclines, although they are rare in childhood $[15,133]$. Co-detection and relative quantification of the aforementioned tumor genetic signature in single blast cells by SCS is anticipated to provide more accurate, previously unraveled prognostic information for patient stratification as it was seen in other cancer types [134,135].

In pediatric leukemia, interrogation of recurrent genomic aberrations at the single-cell level seems especially be crucial in the light of some recent studies that have deeply scrutinized the association of clonal and subclonal alterations with clinical outcome. Jerchel et al. analyzed RAS pathway mutations in B-ALL and found that clonal but not subclonal aberrations are associated with dismal clinical outcome [136]. Antic et al. assessed the clinical relevance of subclonal alterations in eight relapse-associated genes, including CREBBP, IKZF1, KRAS, NRAS, NT5C2, PTPN11, TP53, and WHSC1, and found no correlation between these aberrations and unfavorable clinical outcome [137]. On the other hand, Barz et al. analyzed NT5C2 mutations in a large cohort of relapsed ALL patients and observed that subclonal but not clonal mutations were associated with inferior EFS and with a higher nonresponse rate to relapse treatment. Nonetheless, in the vast majority of cases, these subclonal NT5C2 mutations disappeared by the time of treatment failure or second relapse, indicating that mechanisms driving relapse progression have a previously underappreciated complexity and cannot just simply be attributed to mutations associated with the occurrence of the first relapse [138]. These examples clearly highlight the need for a deeper understanding of progression- and resistance-associated subclonal dynamics in pediatric leukemia, which could be greatly facilitated by SCS.

\section{Emerging Targeted Therapies and Related Clinical Decision Making}

Targeted molecular inhibition of cancer growth has had a previously unprecedented impact on the pharmaceutical industry: in the 2010s, the United States Food and Drug Administration (FDA) approved more small-molecule targeted agents (SMTAs) than altogether in the previous six decades (Figure 1). Development and widespread introduction of a new agent in clinical care takes several years; yet, there are more than 60 clinical trials in 2021 investigating SMTAs on the basis of fulfilled molecular genetics criteria in pediatric AL [139]. Considering the on-label indications, 12 targeted anticancer agents or combinations are approved by FDA for the treatment of AL in the United States (listed as a caption in Figure 1). Three of them are immunotherapy products, and only four of them have an on-label indication in childhood AL. We investigated what proportion of pediatric AL population would be eligible for the on- or off-label use of the nine SMTAs based on genetic features (Figure 2a). In total, only $14.4 \%$ of pediatric patients meet either of the current indication criteria. Additionally, we estimated the proportion of children with AL who could benefit from the use of these SMTAs indicated in AL based on literature data on overall response rates (ORR) to the certain agents (Figure 2b) [140-146]. According to our calculations, $8.9 \%$ of pediatric ALL patients could potentially benefit from SMTAs indicated in AL; however, ORR moves on a wide scale between 40 and $85 \%$. These results suggest a currently low level of genetic data utilization in pediatric AL therapy, while 
the rise of this rate is reasonable to expect in the future. To date, several SMTAs are only demonstrated to be effective in preclinical models (xenografts and cell lines) of AL or labeled in other types of cancer. The application of targeted agent options listed in Table 1 relies partially on such results and not on successful clinical trials. Certainly, the indication of new SMTAs typically broadens over time; hence, those can eventually be used in a broader range of tumor types. TKIs deserve higher attention, as they constitute a backbone of $B C R-A B L 1^{+}$pediatric ALL treatment. The introduction of TKIs brought a breakthrough in the cure of this patient group, which previously had aHSCT as the only efficient treatment option. Recently, TKI administration has also emerged in other genetic subgroups. A surprisingly rapid and durable response was observed to dasatinib in NUP214-ABL1 ${ }^{+}$ T-cell and NCOR1-LYN-fusion-positive BCR-ABL1-like ALL patients [112,147]. Subgroups of $B C R-A B L 1$-like ALL may constitute firm druggable entities (Table 1), but more clinical data is needed to confirm the efficacy of SMTAs in this group. In pediatric AML, several genomic-transcriptomic alterations manifest in an age-dependent manner. For example, KMT2A and NUP98 rearrangements are typically prevalent in childhood, while mutations in IDH1, IDH2, and DNMT3A appear in adult AML [144]. Consequently, SMTAs developed for adult AML are difficult to match with pediatric treatment guidelines.

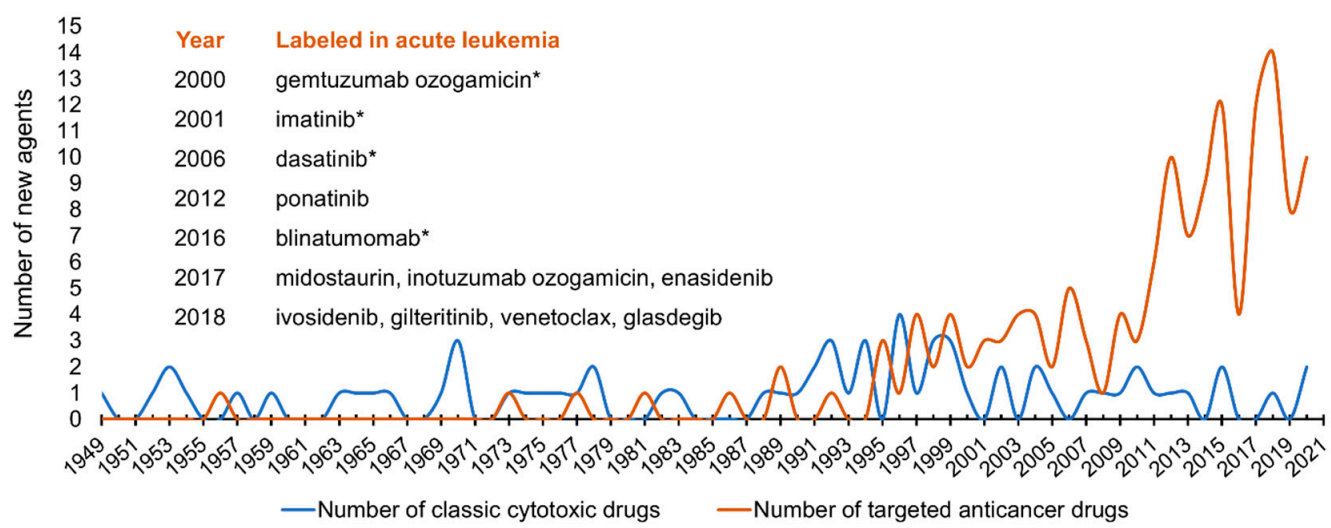

Figure 1. Emergence of anticancer drugs as approved by the United States Food and Drug Administration. Small-molecule targeted agents with acquired label in acute leukemia are specifically indicated. Agents with on-label approval in pediatric leukemia are marked with asterisk $\left(^{*}\right)$.

Availability and affordability of genomic profiling conferred by the spread and decreasing cost of NGS facilitated the utilization of genetic data in clinical decision making. Over the past decade, parallel progress in genomics technologies and genomics-driven drug discovery has created an opportunity to test whether a broader knowledge of genetic aberrations present in an individual's tumor can guide treatment selection and lead to improved outcome of a certain patient. The clinical team responsible for childhood cancer care had to capitalize this opportunity and establish pipelines encompassing all steps from in-depth tumor characterization to personalized treatment suggestions. This ambition founded multidisciplinary molecular tumor boards (MTBs) composed of experts, including members from pediatric oncology/hematology, molecular pathology, cytogenetics, medical genetics, cancer biology, and bioinformatics. MTBs usually hold weekly meetings to discuss all patient related results and suggest treatment modifications or genetic counseling if a cancer-risk gene constellation has been uncovered. As examples, some highly organized pediatric MTBs are listed in Table 3. Between 2012-2018, more than 700 pediatric patients were analyzed by deep genomic characterization, e.g., WES or array comparative genomic hybridization [148-154]. SCS was not documented as an examination method in these studies. Approximately $15 \%$ of the included patients were referred with AL. Targetable genomic alterations were identified in $64 \%$ of them. Individualized interventions were taken in only $13 \%$ of the cases based on actionable integrative clinical sequencing findings. The most common reasons for the limited use of SMTAs was the paucity of safety and 
efficacy data in pediatric tumors, limiting the motivation of treating physicians to offer these treatment options to their patients. Additionally, the process required to obtain non-approved experimental drugs for pediatric patients is time consuming, and the access to these drugs is rarely granted for younger patients. The above-mentioned numbers underline the urgent need for expanded, biomarker-driven, cross-entity phase I/II combination trials for pediatric patients.

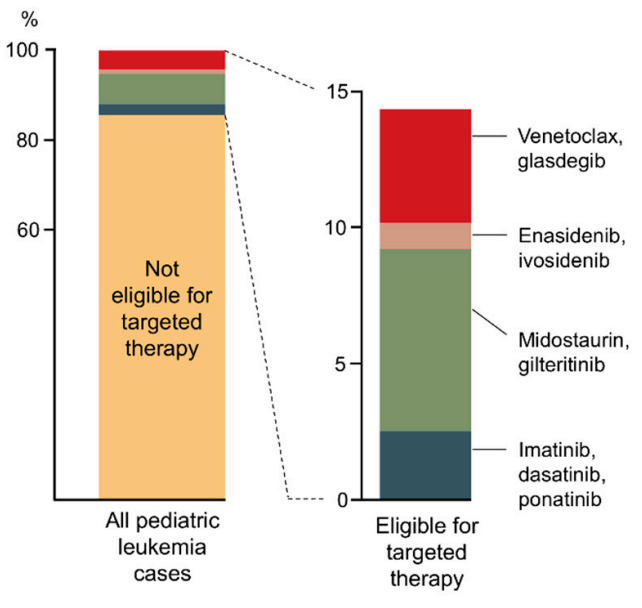

(a)

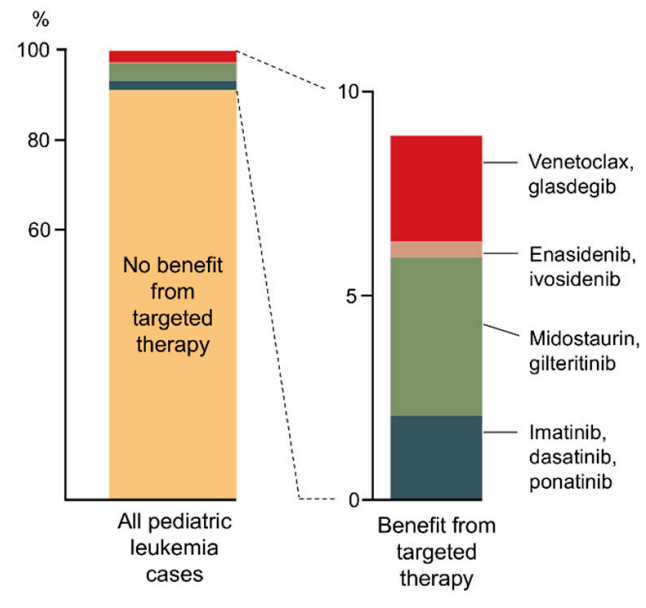

(b)

Figure 2. Current niche and estimated efficacy of small-molecule targeted agents in the clinical management of pediatric acute leukemia. (a) Proportion of patients with pediatric acute leukemia who are eligible for targeted drugs with on-label indications in acute leukemia based on genetic features. (b) Estimated proportion of children with acute leukemia who are expected to benefit from the currently available, on-label small-molecule targeted therapies based on average overall response rates.

Table 3. Some examples of tumor genome profiling and pediatric molecular tumor board (MTB) initiatives in hematological or solid tumor cases.

\begin{tabular}{|c|c|c|c|c|}
\hline $\begin{array}{l}\text { Name of MTB } \\
\text { (Country) }\end{array}$ & Launch Year & New Aspects, Perspectives & $\begin{array}{l}\text { Leukemia } \\
\text { Included }\end{array}$ & Refs \\
\hline $\begin{array}{l}\text { iCAT } \\
\text { (United States) }\end{array}$ & 2012 & $\begin{array}{l}\text { - Identification of translocations is needed early in the disease } \\
\text { course when clarification of diagnosis may lead to a change } \\
\text { in therapeutic approach }\end{array}$ & No & [154] \\
\hline $\begin{array}{l}\text { Peds-MiOncoSeq } \\
\text { (United States) }\end{array}$ & 2012 & $\begin{array}{l}\text { - Novel aberrations can be identified by comprehensive } \\
\text { genomic profiling, which suggest new directions in } \\
\text { translational research (e.g., this study described } A L K \text { fusion } \\
\text { in rhabdomyosarcoma and NTRK1 fusion in } \\
\text { infantile fibrosarcoma) }\end{array}$ & Yes & [153] \\
\hline $\begin{array}{l}\text { PIPseq } \\
\text { (United States) }\end{array}$ & 2014 & $\begin{array}{l}\text { - Challenging diagnoses could be clarified (e.g., Maffucci } \\
\text { syndrome, AMKL, gamma-delta T-cell lymphoma) } \\
\text { - Inclusion of RNA-seq in a sequencing platform is highly } \\
\text { advantageous because it can trustfully identify fusions } \\
\text { which are frequently targetable }\end{array}$ & Yes & [150] \\
\hline $\begin{array}{l}\text { TRICEPS } \\
\text { (Canada) }\end{array}$ & 2014 & $\begin{array}{l}\text { - Tumor mutational burden (TMB) analysis can identify } \\
\text { pediatric highly mutated tumors, which are candidates } \\
\text { for immunotherap } \\
\text { About } 10 \% \text { of patients carry an underlying hereditary } \\
\text { cancer-predisposition gene, making the identification of } \\
\text { relevant germline variants inevitable during } \\
\text { NGS experiments }\end{array}$ & Yes & [151] \\
\hline
\end{tabular}


Table 3. Cont.

\begin{tabular}{|c|c|c|c|c|}
\hline $\begin{array}{l}\text { Name of MTB } \\
\text { (Country) }\end{array}$ & Launch Year & New Aspects, Perspectives & $\begin{array}{l}\text { Leukemia } \\
\text { Included }\end{array}$ & Refs \\
\hline $\begin{array}{l}\text { INFORM } \\
\text { (Germany) }\end{array}$ & 2015 & $\begin{array}{l}\text { - The whole workflow from sample processing to target report } \\
\text { discussed by MTB experts takes } 28 \text { days } \\
\text { A unique prioritization algorithm was introduced to } \\
\text { categorize druggable and tumor biologically relevant } \\
\text { molecular findings }\end{array}$ & Yes & [148] \\
\hline $\begin{array}{l}\text { LEAP } \\
\text { (United States) }\end{array}$ & 2016 & $\begin{array}{l}\text { NGS panels should be part of the standard leukemia } \\
\text { diagnostic evaluation for all pediatric patients }\end{array}$ & No & [149] \\
\hline $\begin{array}{l}\text { ZERO } \\
\text { (Australia) }\end{array}$ & 2017 & $\begin{array}{l}\text { - Invitro, high-throughput drug screening and patient-derived } \\
\text { xenograft drug efficacy testing also helped clinical deci- } \\
\text { sion making }\end{array}$ & Yes & [152] \\
\hline
\end{tabular}

Abbreviations: INFORM, Individualized Therapy for Relapsed Malignancies in Childhood; LEAP, Leukemia Precision-based Therapy; NGS, next generation sequencing; PIPseq, Precision in Pediatric Sequencing Program; RNA-seq, ribonucleic acid sequencing; AMKL, acute megakaryoblastic leukemia; TMB, tumor mutational burden; iCAT, Individualized Cancer Therapy; ZERO, Zero Childhood Cancer.

Hopefully, the precision oncology approaches will be further accelerated by SCS, which may drive the clinicians' choice and widen the indication spectrum of SMTAs. A cell line study by McFarland et al. proposed that long-term effect of an SMTA on tumor cell viability might be predicted more precisely based on short-term (6-24 h posttreatment) transcriptional response monitoring than by multiomic characterization of the initial tumor sample [155]. In this study, transcriptional response was profiled by scRNAseq in order to rapidly assess drug sensitivity of primary tumor cells ex vivo, circumventing the labor-intensive and time-consuming tasks of primary cell culturing needed to achieve sufficient cell numbers for standard viability tests. Recently, single-cell transcriptomics was also successfully used for examining the effectiveness of prednisolone in eliminating relapse-initiating clones and identifying patients with need for intensified treatment in MLL-rearranged infant ALL [124].

\section{High-Resolution Cellular Characterization for Future Clinical Management}

Studies focusing on the translation of NGS data acquired at single blast level to clinical decision making are in their early infancy. Most clinically oriented SCS experiments provide information on the clonal architecture of leukemia, including very minor subpopulations, and on subclonally co-occurring genetic alterations, which may modify targeted treatment strategies. As mentioned before, special relapse-fated blast subpopulations, so-called diagnosis relapse-initiating (dRI) clones, can be identified prior to chemotherapy initiation in childhood B-cell precursor ALL [126]. These subclones are both genetically and transcriptionally related to relapse and have a common ability to populate various leukemic compartments in the patient's body. Clonal divergence of leukemic cells between the central nervous system (CNS) and bone marrow niche was suspected in a subset of patients based on previous high-throughput bulk Ig segment sequencing results by Bartram et al. [156]. Targeted sequencing by Dobson et al. corroborated these findings by unveiling genetic discordance between CNS and bone-marrow-residing blasts in $40 \%$ of examined xenograft models and providing evidence for dRI clone engraftment in the CNS [126].

SCS also aided an advanced understanding of developmental aspects of blast cell biology in childhood ALL [54]. In a study by Caron et al., intraindividual transcriptional clusters were identified in the majority of analyzed patients, which can indicate deregulated genes in potentially resistant subclones. However, the clinical significance of these findings needs further clarification, as it is yet unknown whether blasts at various developmental changes or with variable maturation potential have indeed fitness advantage during chemotherapy. In ETV6-RUNX1 $1^{+}$ALL, scRNA-seq revealed elevated activity of B-lineage differentiation transcription factors ( $\mathrm{TFs}$ ), also including the former leukemia genome-wide association study hit ETS domain-containing protein Elk-3 (ELK3) [58]. Leukemic TF activities persist during chemotherapy and thus provide potentially exploitable vulnera- 
bility option to overcome resistance. SMTAs targeting ETS-family TFs, like ELK3, proved to be effective in drug-resistant leukemic cells. Developmental arrest in T-cell ALL was identified by scRNA-seq as well. Consequent differential activation of pre-TCR LCK and B-cell lymphoma 2 (BCL2) signaling provide new opportunities for targeted therapy, as Gocho et al. described association of kinase inhibitor dasatinib sensitivity with pre-TCR LCK activation level [157].

SCS datasets also identified therapeutically relevant information in JMML hematopoietic stem/progenitor cells (HSPCs), where reduced clonogenicity and induced apoptosis was observed after glucose transporter 1 (GLUT1) inhibitor treatment, which seemed to be synergistic with mitogen-activated extracellular signal-regulated kinase (MEK) inhibition [37]. Even aHSCT, the only curative therapy in JMML, carries a high rate of relapse that is often difficult to recognize immediately. At a relapse following aHSCT, Louka et al. showed striking recurrence of mutant HSPCs resembling the same phenotype identified at JMML diagnosis. Interestingly albeit not surprisingly, these mutant HSPCs were present before profound molecular or clinical evidence of relapse. In an extraordinary case of a young adult with $I D H 1^{+}$AML, SCS demonstrated clonal dominance gain after targeted therapy [158]. Expansion of an originally very minor JAK2 V617F mutated cell subset (variant allele frequency at AML diagnosis: 0.6\%) was observed as a response to selection pressure conferred by multiple lines of chemotherapy and isocitrate dehydrogenase 1 (IDH1) inhibitor ivosidenib treatment. Single-cell analysis greatly helped to deconvolute the clonal architecture of the patient's myeloid malignancy, as it revealed shared JAK2 and IDH1 mutations in the majority of subclones. In such a case, combination therapy of SMTAs might be highly beneficial relative to Janus kinase (JAK) or IDH inhibitor monotherapy, as previously published preclinical data suggest [159].

These examples demonstrate the potential of SCS to support decision making in a clinical environment, but further translational studies are clearly required for clarifying the robustness of the method and for assessing the feasibility of its implementation in the diagnostic workflow of pediatric leukemia. Strikingly, SCS has started to emerge in currently running clinical trials with an aim to pinpoint the cell of origin of leukemogenic alterations formed in utero or to assess clonal diversity and evolution of pre-leukemic and leukemic populations with a view to correlate these findings with somatic mutation monitoring, in vitro chemotherapy resistance, MRD, and patient outcome $[160,161]$.

\section{Conclusions}

SCS has been expanding our knowledge of the biological background of pediatric leukemia, and several studies reported novel findings with direct or indirect therapeutic relevance, potentially influencing the clinical management of patients in the future. Driven by recent technological advancements, the number of simultaneously analyzable cells and approaches supporting multimodal data generation have been permanently increasing, paving the way towards a comprehensive multiomic data landscape. The current number of papers reporting single-cell studies in pediatric leukemia is still very limited, and the widespread application of SCS methods in general faces multiple challenges posed by data sparsity, quantitative uncertainty, incomplete reference databases, relatively high cost, batch effects, and the rapid emergence of computational tools developed outside the recommended frameworks of standardized benchmarking [74]. The practical potential of SCS in large-scale research programs and clinical applications will be determined by its robustness and flexibility under non-uniform wet-lab and dry-lab conditions, which will likely require widely accepted, high-level consensus on methodological considerations [162]. From an evolutionary perspective, the fundamental unit of selection is the single cell, and in this regard, SCS enables a deep characterization of neoplasms with an ultimate resolution; however, the full potential of SCS methods can only be exploited with a more profound incorporation of evolutionary principles into the clinical decision making system of pediatric leukemia [163]. 
Author Contributions: D.A. and B.E. designed the structure of the paper and wrote the manuscript with contributions from C.B. and G.T.K. All authors have read, critically reviewed and agreed to the published the final version of the manuscript.

Funding: This study was funded by the Hungarian National Research, Development, and Innovation Office (NKFIH) (FK20_134253, K21_137948 and ED18-1-2019-0019), by the EU's Horizon 2020 research and innovation program (No. 739593), by a János Bolyai Research Scholarship (BO/00320/18/5) of the Hungarian Academy of Sciences, by the Hungarian Pediatric Oncology Network (03/MGYHMGYGYT/2021), by the New National Excellence Program and Co-operative Doctoral Program of the Ministry for Innovation and Technology (ÚNKP-20-5-SE-22, ÚNKP-20-3-II-SE-20 and KDP-20201008491), as well as by the Complementary Research Excellence Program of Semmelweis University (EFOP-3.6.3-VEKOP-16-2017-00009), the Higher Education Institutional Excellence Programme of the Ministry of Human Capacities in Hungary within the framework of the Molecular Biology thematic programme of the Semmelweis University, and the ELIXIR Hungary.

Conflicts of Interest: The authors declare no conflict of interest.

\section{References}

1. Fialkow, P.J. Clonal origin of human tumors. Annu. Rev. Med. 1979, 30, 135-143. [CrossRef]

2. Hanahan, D.; Weinberg, R.A. Hallmarks of cancer: The next generation. Cell 2011, 144, 646-674. [CrossRef] [PubMed]

3. Greaves, M.; Maley, C.C. Clonal evolution in cancer. Nature 2012, 481, 306. [CrossRef]

4. Alpar, D.; Barber, L.J.; Gerlinger, M. Genetic Intratumor Heterogeneity. Epigenetic Cancer Ther. 2015, 571-593. [CrossRef]

5. Stephens, P.J.; Greenman, C.D.; Fu, B.; Yang, F.; Bignell, G.R.; Mudie, L.J.; Pleasance, E.D.; Lau, K.W.; Beare, D.; Stebbings, L.A.; et al. Massive genomic rearrangement acquired in a single catastrophic event during cancer development. Cell 2011, 144, 27-40. [CrossRef]

6. Vogelstein, B.; Papadopoulos, N.; Velculescu, V.E.; Zhou, S.; Diaz, L.A.; Kinzler, K.W. Cancer genome landscapes. Science 2013, 340, 1546-1558. [CrossRef]

7. Alsagaby, S.A. Omics-based insights into therapy failure of pediatric B-lineage acute lymphoblastic leukemia. Oncol. Rev. 2019, 13, 149-155. [CrossRef]

8. Arber, D.; Orazi, A.; Hasserjian, R.; Thiele, J.; Borowitz, M.; Le Beau, M.; Bloomfield, C.; Cazzola, M.; Vardiman, J. The 2016 revision to the World Health Organization classification of myeloid neoplasms and acute leukemia. Blood 2016, 127, 2391-2405. [CrossRef] [PubMed]

9. Swerdlow, S.H.; Campo, E.; Pileri, S.A.; Lee Harris, N.; Stein, H.; Siebert, R.; Advani, R.; Ghielmini, M.; Salles, G.A.; Zelenetz, A.D.; et al. The 2016 revision of the World Health Organization classification of lymphoid neoplasms. Blood 2016, 127, 2375-2390. [CrossRef] [PubMed]

10. Zhan, F.; Huang, Y.; Colla, S.; Stewart, J.P.; Hanamura, I.; Gupta, S.; Epstein, J.; Yaccoby, S.; Sawyer, J.; Burington, B.; et al. The molecular classification of multiple myeloma. Blood 2006, 108, 2020-2028. [CrossRef]

11. Kumar-Sinha, C.; Chinnaiyan, A.M. Precision oncology in the age of integrative genomics. Nat. Biotechnol. 2018, 36, 46. [CrossRef]

12. Leblanc, V.G.; Marra, M.A. Next-generation sequencing approaches in cancer: Where have they brought us and wherewill they take us? Cancers 2015, 7, 1925-1958. [CrossRef]

13. Gu, Z.; Churchman, M.L.; Roberts, K.G.; Moore, I.; Zhou, X.; Nakitandwe, J.; Hagiwara, K.; Pelletier, S.; Gingras, S.; Berns, H.; et al. PAX5-driven subtypes of B-progenitor acute lymphoblastic leukemia. Nat. Genet. 2019, 51, 296-307. [CrossRef] [PubMed]

14. Inaba, H.; Pui, C.-H. Advances in the Diagnosis and Treatment of Pediatric Acute Lymphoblastic Leukemia. J. Clin. Med. 2021, 10, 1926. [CrossRef] [PubMed]

15. Bolouri, H.; Farrar, J.E.; Triche, T.; Ries, R.E.; Lim, E.L.; Alonzo, T.A.; Ma, Y.; Moore, R.; Mungall, A.J.; Marra, M.A.; et al. The molecular landscape of pediatric acute myeloid leukemia reveals recurrent structural alterations and age-specific mutational interactions. Nat. Med. 2018, 24, 103-112. [CrossRef] [PubMed]

16. Gerlinger, M.; Rowan, A.J.; Horswell, S.; Larkin, J.; Endesfelder, D.; Gronroos, E.; Martinez, P.; Matthews, N.; Stewart, A.; Tarpey, P.; et al. Intratumor Heterogeneity and Branched Evolution Revealed by Multiregion Sequencing. N. Engl. J. Med. 2012, 366, 883-892. [CrossRef] [PubMed]

17. McGranahan, N.; Swanton, C. Clonal Heterogeneity and Tumor Evolution: Past, Present, and the Future. Cell 2017, 168, 613-628. [CrossRef] [PubMed]

18. Turajlic, S.; Sottoriva, A.; Graham, T.; Swanton, C. Resolving genetic heterogeneity in cancer. Nat. Rev. Genet. 2019, 20, 404-416. [CrossRef]

19. Wu, Y.; Yang, S.; Ma, J.; Chen, Z.; Song, G.; Rao, D.; Cheng, Y.; Huang, S.; Liu, Y.; Jiang, S.; et al. Spatiotemporal Immune Landscape of Colorectal Cancer Liver Metastasis at Single-Cell Level. Cancer Discov. 2021, candisc.0316.2021. [CrossRef]

20. Lei, Y.; Tang, R.; Xu, J.; Wang, W.; Zhang, B.; Liu, J.; Yu, X.; Shi, S. Applications of single-cell sequencing in cancer research: Progress and perspectives. J. Hematol. Oncol. 2021, 14, 91. [CrossRef]

21. Gupta, S.D.; Sachs, Z. Novel single-cell technologies in acute myeloid leukemia research. Transl. Res. 2017, 189, 123-135. [CrossRef] [PubMed] 
22. Macaulay, I.C.; Ponting, C.P.; Voet, T. Single-Cell Multiomics: Multiple Measurements from Single Cells. Trends Genet. 2017, 33, 155-168. [CrossRef]

23. Greaves, M. Leukaemia "firsts" in cancer research and treatment. Nat. Rev. Cancer 2016, 16, 163-172. [CrossRef]

24. Zhu, Y.; Huang, Y.; Tan, Y.; Zhao, W.; Tian, Q. Single-Cell RNA Sequencing in Hematological Diseases. Proteomics 2020, $20,1900228$. [CrossRef] [PubMed]

25. García-sanz, R.; Jiménez, C. Time to move to the single-cell level: Applications of single-cell multi-omics to hematological malignancies and waldenström's macroglobulinemia-A particularly heterogeneous lymphoma. Cancers (Basel) 2021, $13,1541$. [CrossRef] [PubMed]

26. Lohr, J.G.; Kim, S.; Gould, J.; Knoechel, B.; Drier, Y.; Cotton, M.J.; Gray, D.; Birrer, N.; Wong, B.; Ha, G.; et al. Genetic interrogation of circulating multiple myeloma cells at single-cell resolution. Sci. Transl. Med. 2016, 8, 363ra147. [CrossRef]

27. Jan, M.; Snyder, T.M.; Corces-Zimmerman, M.R.; Vyas, P.; Weissman, I.L.; Quake, S.R.; Majeti, R. Clonal evolution of preleukemic hematopoietic stem cells precedes human acute myeloid leukemia. Sci. Transl. Med. 2012, 4, 149ra118. [CrossRef]

28. Shi, M.; Dong, X.; Huo, L.; Wei, X.; Wang, F.; Sun, K. The potential roles and advantages of single cell sequencing in the diagnosis and treatment of hematological malignancies. In Advances in Experimental Medicine and Biology; Springer: New York, NY, USA, 2018; Volume 1068, pp. 119-133.

29. Giustacchini, A.; Thongjuea, S.; Barkas, N.; Woll, P.S.; Povinelli, B.J.; Booth, C.A.G.; Sopp, P.; Norfo, R.; Rodriguez-Meira, A.; Ashley, N.; et al. Single-cell transcriptomics uncovers distinct molecular signatures of stem cells in chronic myeloid leukemia. Nat. Med. 2017, 23, 692-702. [CrossRef]

30. Hou, Y.; Song, L.; Zhu, P.; Zhang, B.; Tao, Y.; Xu, X.; Li, F.; Wu, K.; Liang, J.; Shao, D.; et al. Single-cell exome sequencing and monoclonal evolution of a JAK2-negative myeloproliferative neoplasm. Cell 2012, 148, 873-885. [CrossRef]

31. Taylor, J.; Mi, X.; North, K.; Binder, M.; Penson, A.; Lasho, T.; Knorr, K.; Haddadin, M.; Liu, B.; Pangallo, J.; et al. Single-cell genomics reveals the genetic and molecular bases for escape from mutational epistasis in myeloid neoplasms. Blood 2020, 136, 1477-1486. [CrossRef]

32. Sachs, K.; Sarver, A.L.; Noble-Orcutt, K.E.; LaRue, R.S.; Antony, M.L.; Chang, D.; Lee, Y.; Navis, C.M.; Hillesheim, A.L.; Nykaza, I.R.; et al. Single-cell gene expression analyses reveal distinct self-renewing and proliferating subsets in the leukemia stem cell compartment in acute myeloid leukemia. Cancer Res. 2020, 80, 458-470. [CrossRef]

33. Smith, C.C.; Paguirigan, A.; Jeschke, G.R.; Lin, K.C.; Massi, E.; Tarver, T.; Chin, C.-S.; Asthana, S.; Olshen, A.; Travers, K.J.; et al. Heterogeneous resistance to quizartinib in acute myeloid leukemia revealed by single-cell analysis. Blood 2017, 130, 48-58. [CrossRef]

34. Stetson, L.; Balasubramanian, D.; Ribeiro, S.; Stefan, T.; Gupta, K.; Xu, X.; Fourati, S.; Roe, A.; Jackson, Z.; Schauner, R.; et al. Single cell RNA sequencing of AML initiating cells reveals RNA-based evolution during disease progression. Leukemia 2021, 35, 2799-2812. [CrossRef] [PubMed]

35. Van Galen, P.; Hovestadt, V.; Wadsworth, M.H.; Hughes, T.K.; Griffin, G.K.; Battaglia, S.; Verga, J.A.; Stephansky, J.; Pastika, T.J.; Lombardi Story, J.; et al. Single-Cell RNA-Seq Reveals AML Hierarchies Relevant to Disease Progression and Immunity. Cell 2019, 176, 1265-1281.e24. [CrossRef]

36. Demaree, B.; Delley, C.L.; Vasudevan, H.N.; Peretz, C.A.C.; Ruff, D.; Smith, C.C.; Abate, A.R. Joint profiling of DNA and proteins in single cells to dissect genotype-phenotype associations in leukemia. Nat. Commun. 2021, 12, 1583. [CrossRef]

37. Louka, E.; Povinelli, B.; Rodriguez-Meira, A.; Buck, G.; Wen, W.X.; Wang, G.; Sousos, N.; Ashley, N.; Hamblin, A.; Booth, C.A.G.; et al. Heterogeneous disease-propagating stem cells in juvenile myelomonocytic leukemia. J. Exp. Med. 2021, 218, e20180853. [CrossRef]

38. Walter, C.; Pozzorini, C.; Reinhardt, K.; Geffers, R.; Xu, Z.; Reinhardt, D.; von Neuhoff, N.; Hanenberg, H. Single-cell whole exome and targeted sequencing in NPM1/FLT3 positive pediatric acute myeloid leukemia. Pediatr. Blood Cancer 2018, 65, e26848. [CrossRef]

39. Chen, J.; Kao, Y.R.; Sun, D.; Todorova, T.I.; Reynolds, D.; Narayanagari, S.R.; Montagna, C.; Will, B.; Verma, A.; Steidl, U. Myelodysplastic syndrome progression to acute myeloid leukemia at the stem cell level. Nat. Med. 2019, 25, 103-110. [CrossRef] [PubMed]

40. Ediriwickrema, A.; Aleshin, A.; Reiter, J.G.; Corces, M.R.; Kohnke, T.; Stafford, M.; Liedtke, M.; Medeiros, B.C.; Majeti, R. Single-cell mutational profiling enhances the clinical evaluation of AML MRD. Blood Adv. 2020, 4, 943-952. [CrossRef]

41. Hughes, A.E.O.; Magrini, V.; Demeter, R.; Miller, C.A.; Fulton, R.; Fulton, L.L.; Eades, W.C.; Elliott, K.; Heath, S.; Westervelt, P.; et al. Clonal Architecture of Secondary Acute Myeloid Leukemia Defined by Single-Cell Sequencing. PLoS Genet. 2014, 10, e1004462. [CrossRef] [PubMed]

42. McMahon, C.M.; Ferng, T.; Canaani, J.; Wang, E.S.; Morrissette, J.J.D.; Eastburn, D.J.; Pellegrino, M.; Durruthy-Durruthy, R.; Watt, C.D.; Asthana, S.; et al. Clonal selection with RAS pathway activation mediates secondary clinical resistance to selective FLT3 inhibition in acute myeloid leukemia. Cancer Discov. 2019, 9, 1050-1063. [CrossRef]

43. Miles, L.A.; Bowman, R.L.; Merlinsky, T.R.; Csete, I.S.; Ooi, A.T.; Durruthy-Durruthy, R.; Bowman, M.; Famulare, C.; Patel, M.A.; Mendez, P.; et al. Single-cell mutation analysis of clonal evolution in myeloid malignancies. Nature 2020, 587, 477-482. [CrossRef] [PubMed]

44. Morita, K.; Wang, F.; Jahn, K.; Hu, T.; Tanaka, T.; Sasaki, Y.; Kuipers, J.; Loghavi, S.; Wang, S.A.; Yan, Y.; et al. Clonal evolution of acute myeloid leukemia revealed by high-throughput single-cell genomics. Nat. Commun. 2020, 11, 5327. [CrossRef] 
45. Pellegrino, M.; Sciambi, A.; Treusch, S.; Durruthy-Durruthy, R.; Gokhale, K.; Jacob, J.; Chen, T.X.; Geis, J.A.; Oldham, W.; Matthews, J.; et al. High-throughput single-cell DNA sequencing of acute myeloid leukemia tumors with droplet microfluidics. Genome Res. 2018, 28, 1345-1352. [CrossRef]

46. Petti, A.A.; Williams, S.R.; Miller, C.A.; Fiddes, I.T.; Srivatsan, S.N.; Chen, D.Y.; Fronick, C.C.; Fulton, R.S.; Church, D.M.; Ley, T.J. A general approach for detecting expressed mutations in AML cells using single cell RNA-sequencing. Nat. Commun. 2019, 10, 3660. [CrossRef] [PubMed]

47. Gawad, C.; Koh, W.; Quake, S.R. Dissecting the clonal origins of childhood acute lymphoblastic leukemia by single-cell genomics. Proc. Natl. Acad. Sci. USA 2014, 111, 17947-17952. [CrossRef]

48. Ebinger, S.; Özdemir, E.Z.; Ziegenhain, C.; Tiedt, S.; Castro Alves, C.; Grunert, M.; Dworzak, M.; Lutz, C.; Turati, V.A.; Enver, T.; et al. Characterization of Rare, Dormant, and Therapy-Resistant Cells in Acute Lymphoblastic Leukemia. Cancer Cell 2016, 30, 849-862. [CrossRef]

49. Witkowski, M.T.; Dolgalev, I.; Evensen, N.A.; Ma, C.; Chambers, T.; Roberts, K.G.; Sreeram, S.; Dai, Y.; Tikhonova, A.N.; Lasry, A.; et al. Extensive Remodeling of the Immune Microenvironment in B Cell Acute Lymphoblastic Leukemia. Cancer Cell 2020, 37, 867-882.e12. [CrossRef] [PubMed]

50. Wu, L.; Jiang, M.; Yu, P.; Li, J.; Ouyang, W.; Feng, C.; Zhao, W.L.; Dai, Y.; Huang, J. Single-Cell Transcriptome Analysis Identifies Ligand-Receptor Pairs Associated With BCP-ALL Prognosis. Front. Oncol. 2021, 11, 322. [CrossRef]

51. Zhu, H.; Zhang, L.; Wu, Y.; Dong, B.; Guo, W.; Wang, M.; Yang, L.; Fan, X.; Tang, Y.; Liu, N.; et al. T-ALL leukemia stem cell 'stemness' is epigenetically controlled by the master regulator SPI1. Elife 2018, 7, e38314. [CrossRef]

52. Albertí-Servera, L.; Demeyer, S.; Govaerts, I.; Swings, T.; De Bie, J.; Gielen, O.; Brociner, M.; Michaux, L.; Maertens, J.; Uyttebroeck, A.; et al. Single-cell DNA amplicon sequencing reveals clonal heterogeneity and evolution in T-cell acute lymphoblastic leukemia. Blood 2021, 137, 801-811. [CrossRef]

53. Anand, P.; Guillaumet-Adkins, A.; Dimitrova, V.; Yun, H.; Drier, Y.; Sotudeh, N.; Rogers, A.; Ouseph, M.M.; Nair, M.; Potdar, S.; et al. Single-cell RNA-seq reveals developmental plasticity with coexisting oncogenic states and immune evasion programs in ETP-ALL. Blood 2021, 137, 2463-2480. [CrossRef]

54. Caron, M.; St-Onge, P.; Sontag, T.; Wang, Y.C.; Richer, C.; Ragoussis, I.; Sinnett, D.; Bourque, G. Single-cell analysis of childhood leukemia reveals a link between developmental states and ribosomal protein expression as a source of intra-individual heterogeneity. Sci. Rep. 2020, 10, 8079. [CrossRef] [PubMed]

55. De Bie, J.; Demeyer, S.; Alberti-Servera, L.; Geerdens, E.; Segers, H.; Broux, M.; De Keersmaecker, K.; Michaux, L.; Vandenberghe, P.; Voet, T.; et al. Single-cell sequencing reveals the origin and the order of mutation acquisition in T-cell acute lymphoblastic leukemia. Leukemia 2018, 32, 1358-1369. [CrossRef] [PubMed]

56. Easton, J.; Gonzalez-Pena, V.; Yergeau, D.; Ma, X.; Gawad, C. Genome-wide segregation of single nucleotide and structural variants into single cancer cells. BMC Genom. 2017, 18, 906. [CrossRef] [PubMed]

57. Li, J.-F.; Dai, Y.-T.; Lilljebjörn, H.; Shen, S.-H.; Cui, B.-W.; Bai, L.; Liu, Y.-F.; Qian, M.-X.; Huang, J.-Y. Transcriptional landscape of B cell precursor acute lymphoblastic leukemia based on an international study of 1,223 cases. Proc. Natl. Acad. Sci. USA 2018, 115, E11711-E11720. [CrossRef] [PubMed]

58. Mehtonen, J.; Teppo, S.; Lahnalampi, M.; Kokko, A.; Kaukonen, R.; Oksa, L.; Bouvy-Liivrand, M.; Malyukova, A.; Mäkinen, A.; Laukkanen, S.; et al. Single cell characterization of B-lymphoid differentiation and leukemic cell states during chemotherapy in ETV6-RUNX1-positive pediatric leukemia identifies drug-targetable transcription factor activities. Genome Med. 2020, 12, 99. [CrossRef]

59. Penter, L.; Gohil, S.H.; Lareau, C.; Ludwig, L.S.; Parry, E.M.; Huang, T.; Li, S.; Zhang, W.; Livitz, D.; Leshchiner, I.; et al. Longitudinal single-cell dynamics of chromatin accessibility and mitochondrial mutations in chronic lymphocytic leukemia mirror disease history. Cancer Discov. 2021, candisc.0276.2021. [CrossRef]

60. Rendeiro, A.F.; Krausgruber, T.; Fortelny, N.; Zhao, F.; Penz, T.; Farlik, M.; Schuster, L.C.; Nemc, A.; Tasnády, S.; Réti, M.; et al. Chromatin mapping and single-cell immune profiling define the temporal dynamics of ibrutinib response in CLL. Nat. Commun. 2020, 11, 577. [CrossRef]

61. Roider, T.; Seufert, J.; Uvarovskii, A.; Frauhammer, F.; Bordas, M.; Abedpour, N.; Stolarczyk, M.; Mallm, J.P.; Herbst, S.A.; Bruch, P.M.; et al. Dissecting intratumour heterogeneity of nodal B-cell lymphomas at the transcriptional, genetic and drug-response levels. Nat. Cell Biol. 2020, 22, 896-906. [CrossRef]

62. Wang, L.; Mo, S.; Li, X.; He, Y.; Yang, J. Single-cell RNA-seq reveals the immune escape and drug resistance mechanisms of mantle cell lymphoma. Cancer Biol. Med. 2020, 17, 726-739. [CrossRef]

63. Zhang, S.; Jiang, V.C.; Han, G.; Hao, D.; Lian, J.; Liu, Y.; Zhang, R.; McIntosh, J.; Wang, R.; Dang, M.; et al. Longitudinal single-cell profiling reveals molecular heterogeneity and tumor-immune evolution in refractory mantle cell lymphoma. Nat. Commun. 2021, 12, 2877. [CrossRef]

64. Andor, N.; Simonds, E.F.; Czerwinski, D.K.; Chen, J.; Grimes, S.M.; Wood-Bouwens, C.; Zheng, G.X.Y.; Kubit, M.A.; Greer, S.; Weiss, W.A.; et al. Single-cell RNA-Seq of follicular lymphoma reveals malignant B-cell types and coexpression of T-cell immune checkpoints. Blood 2019, 133, 1119-1129. [CrossRef]

65. Haebe, S.; Shree, T.; Sathe, A.; Day, G.; Czerwinski, D.K.; Grimes, S.M.; Lee, H.J.; Binkley, M.S.; Long, S.R.; Martin, B.; et al. Single-cell analysis can define distinct evolution of tumor sites in follicular lymphoma. Blood 2021, 137, 2869-2880. [CrossRef] 
66. Milpied, P.; Cervera-Marzal, I.; Mollichella, M.L.; Tesson, B.; Brisou, G.; Traverse-Glehen, A.; Salles, G.; Spinelli, L.; Nadel, B. Human germinal center transcriptional programs are de-synchronized in B cell lymphoma. Nat. Immunol. 2018, 19, 1013-1024. [CrossRef]

67. Mitra, A.K.; Mukherjee, U.K.; Harding, T.; Jang, J.S.; Stessman, H.; Li, Y.; Abyzov, A.; Jen, J.; Kumar, S.; Rajkumar, V.; et al. Single-cell analysis of targeted transcriptome predicts drug sensitivity of Longitudinal single-cell profiling reveals molecular heterogeneity and tumor-immune evolution in refractory mantle cell lymphomasingle cells within human myeloma tumors. Leukemia 2016, 30, 1094-1102. [CrossRef]

68. Aoki, T.; Chong, L.C.; Takata, K.; Milne, K.; Hav, M.; Colombo, A.; Chavez, E.A.; Nissen, M.; Wang, X.; Miyata-Takata, T.; et al. Single-cell transcriptome analysis reveals disease-defining $\mathrm{t}$-cell subsets in the tumor microenvironment of classic hodgkin lymphoma. Cancer Discov. 2020, 10, 406-421. [CrossRef]

69. Buus, T.B.; Willerslev-Olsen, A.; Fredholm, S.; Blümel, E.; Nastasi, C.; Gluud, M.; Hu, T.; Lindahl, L.M.; Iversen, L.; Fogh, H.; et al. Single-cell heterogeneity in Sézary syndrome. Blood Adv. 2018, 2, 2115-2126. [CrossRef]

70. Rindler, K.; Bauer, W.M.; Jonak, C.; Wielscher, M.; Shaw, L.E.; Rojahn, T.B.; Thaler, F.M.; Porkert, S.; Simonitsch-Klupp, I.; Weninger, W.; et al. Single-Cell RNA Sequencing Reveals Tissue Compartment-Specific Plasticity of Mycosis Fungoides Tumor Cells. Front. Immunol. 2021, 12, 666935. [CrossRef]

71. Gaydosik, A.M.; Tabib, T.; Geskin, L.J.; Bayan, C.A.; Conway, J.F.; Lafyatis, R.; Fuschiotti, P. Single-cell lymphocyte heterogeneity in advanced cutaneous T-cell lymphoma skin tumors. Clin. Cancer Res. 2019, 25, 4443-4454. [CrossRef]

72. Jonak, C.; Alkon, N.; Rindler, K.; Rojahn, T.B.; Shaw, L.E.; Porkert, S.; Weninger, W.; Trautinger, F.; Stingl, G.; Tschandl, P.; et al. Single-cell RNAseq profiling in a patient with discordant primary cutaneous B and T cell lymphoma reveals micromilieu-driven immune skewing. Br. J. Dermatol. 2021, 185, 1013-1025. [CrossRef]

73. Li, Z.; Wang, H.; Dong, R.; Man, J.; Sun, L.; Qian, X.; Zhu, X.; Cao, P.; Yu, Y.; Le, J.; et al. Single-Cell RNA-seq Reveals Characteristics of Malignant Cells and Immune Microenvironment in Subcutaneous Panniculitis-Like T-Cell Lymphoma. Front. Oncol. 2021, 11, 813. [CrossRef]

74. Lähnemann, D.; Köster, J.; Szczurek, E.; McCarthy, D.J.; Hicks, S.C.; Robinson, M.D.; Vallejos, C.A.; Campbell, K.R.; Beerenwinkel, N.; Mahfouz, A.; et al. Eleven grand challenges in single-cell data science. Genome Biol. 2020, 21, 31. [CrossRef]

75. Huang, X.-T.; Li, X.; Qin, P.-Z.; Zhu, Y.; Xu, S.-N.; Chen, J.-P. Technical Advances in Single-Cell RNA Sequencing and Applications in Normal and Malignant Hematopoiesis. Front. Oncol. 2018, 8, 582. [CrossRef]

76. Ysebaert, L.; Quillet-Mary, A.; Tosolini, M.; Pont, F.; Laurent, C.; Fournié, J.J. Lymphoma Heterogeneity Unraveled by Single-Cell Transcriptomics. Front. Immunol. 2021, 12, 202. [CrossRef]

77. Gianni, F.; Belver, L.; Ferrando, A. The genetics and mechanisms of T-cell acute lymphoblastic leukemia. Cold Spring Harb. Perspect. Med. 2020, 10, a035246. [CrossRef]

78. Greaves, M.F.; Maia, A.T.; Wiemels, J.L.; Ford, A.M. Leukemia in twins: Lessons in natural history. Blood 2003, 102, $2321-2333$. [CrossRef]

79. Greaves, M. Darwin and evolutionary tales in leukemia. The Ham-Wasserman Lecture. Hematol. Am. Soc. Hematol. Educ. Program 2009, 2009, 3-12. [CrossRef]

80. Ma, Y.; Dobbins, S.E.; Sherborne, A.L.; Chubb, D.; Galbiati, M.; Cazzaniga, G.; Micalizzi, C.; Tearle, R.; Lloyd, A.L.; Hain, R.; et al. Developmental timing of mutations revealed by whole-genome sequencing of twins with acute lymphoblastic leukemia. Proc. Natl. Acad. Sci. USA 2013, 110, 7429-7433. [CrossRef]

81. Anderson, K.; Lutz, C.; Van Delft, F.W.; Bateman, C.M.; Guo, Y.; Colman, S.M.; Kempski, H.; Moorman, A.V.; Titley, I.; Swansbury, J.; et al. Genetic variegation of clonal architecture and propagating cells in leukaemia. Nature 2011, 469, 356-361. [CrossRef]

82. Alpar, D.; Wren, D.; Ermini, L.; Mansur, M.B.; Van Delft, F.W.; Bateman, C.M.; Titley, I.; Kearney, L.; Szczepanski, T.; Gonzalez, D.; et al. Clonal origins of ETV6-RUNX1+ acute lymphoblastic leukemia: Studies in monozygotic twins. Leukemia 2015, 29, 839-846. [CrossRef]

83. Mullighan, C.; Phillips, L.; Su, X.; Ma, J.; Miller, C.; Shurtleff, S.; Downing, J. Genomic analysis of the clonal origins of relapsed acute lymphoblastic leukemia. Science 2008, 322, 1377-1380. [CrossRef]

84. Kiss, R.; Gángó, A.; Benard-Slagter, A.; Egyed, B.; Haltrich, I.; Hegyi, L.; de Groot, K.; Király, P.A.; Krizsán, S.; Kajtár, B.; et al. Comprehensive profiling of disease-relevant copy number aberrations for advanced clinical diagnostics of pediatric acute lymphoblastic leukemia. Mod. Pathol. 2020, 33, 812-824. [CrossRef]

85. Li, B.; Brady, S.W.; Ma, X.; Shen, S.; Zhang, Y.; Li, Y.; Szlachta, K.; Dong, L.; Liu, Y.; Yang, F.; et al. Therapy-induced mutations drive the genomic landscape of relapsed acute lymphoblastic leukemia. Blood 2020, 135, 41-55. [CrossRef]

86. Waanders, E.; Gu, Z.; Dobson, S.M.; Antić, Ž.; Crawford, J.C.; Ma, X.; Edmonson, M.N.; Payne-Turner, D.; van de Vorst, M.; Jongmans, M.C.J.; et al. Mutational Landscape and Patterns of Clonal Evolution in Relapsed Pediatric Acute Lymphoblastic Leukemia. Blood Cancer Discov. 2020, 1, 96-111. [CrossRef]

87. Antic, Ž.; Lelieveld, S.H.; Van Der Ham, C.G.; Sonneveld, E.; Hoogerbrugge, P.M.; Kuiper, R.P. Unravelling the sequential interplay of mutational mechanisms during clonal evolution in relapsed pediatric acute lymphoblastic leukemia. Genes (Basel) 2021, 12, 214. [CrossRef]

88. Yang, F.; Brady, S.W.; Tang, C.; Sun, H.; Du, L.; Barz, M.J.; Ma, X.; Chen, Y.; Fang, H.; Li, X.; et al. Chemotherapy and mismatch repair deficiency cooperate to fuel TP53 mutagenesis and ALL relapse. Nat. Cancer 2021, 2, 819-834. [CrossRef] 
89. Nordlund, J.; Syvänen, A.C. Epigenetics in pediatric acute lymphoblastic leukemia. Semin. Cancer Biol. 2018, 51, 129-138. [CrossRef]

90. Nordlund, J.; Bäcklin, C.L.; Zachariadis, V.; Cavelier, L.; Dahlberg, J.; Öfverholm, I.; Barbany, G.; Nordgren, A.; Övernäs, E.; Abrahamsson, J.; et al. DNA methylation-based subtype prediction for pediatric acute lymphoblastic leukemia. Clin. Epigenet. 2015, 7, 11. [CrossRef]

91. Gabriel, A.S.; Lafta, F.M.; Schwalbey, E.C.; Nakjang, S.; Cockell, S.J.; Iliasova, A.; Enshaei, A.; Schwab, C.; Rand, V.; Clifford, S.C.; et al. Epigenetic landscape correlates with genetic subtype but does not predict outcome in childhood acute lymphoblastic leukemia. Epigenetics 2015, 10, 717-726. [CrossRef]

92. Fleur-Lominy, S.; Evensen, N.A.; Bhatla, T.; Sethia, G.; Narang, S.; Choi, J.H.; Ma, X.; Yang, J.J.; Kelly, S.; Raetz, E.; et al. Evolution of the epigenetic landscape in childhood B Acute lymphoblastic leukemia and its role in drug resistance. Cancer Res. 2020, 80, 5189-5202. [CrossRef]

93. Den Boer, M.L.; van Slegtenhorst, M.; De Menezes, R.X.; Cheok, M.H.; Buijs-Gladdines, J.G.; Peters, S.T.; Van Zutven, L.J.; Beverloo, H.B.; Van der Spek, P.J.; Escherich, G.; et al. A subtype of childhood acute lymphoblastic leukaemia with poor treatment outcome: A genome-wide classification study. Lancet Oncol. 2009, 10, 125-134. [CrossRef]

94. Mullighan, C.G.; Su, X.; Zhang, J.; Radtke, I.; Phillips, L.A.A.; Miller, C.B.; Ma, J.; Liu, W.; Cheng, C.; Schulman, B.A.; et al. Deletion of IKZF1 and Prognosis in Acute Lymphoblastic Leukemia. N. Engl. J. Med. 2009, 360, 470-480. [CrossRef]

95. Lilljebjörn, H.; Henningsson, R.; Hyrenius-Wittsten, A.; Olsson, L.; Orsmark-Pietras, C.; Von Palffy, S.; Askmyr, M.; Rissler, M.; Schrappe, M.; Cario, G.; et al. Identification of ETV6-RUNX1-like and DUX4-rearranged subtypes in paediatric B-cell precursor acute lymphoblastic leukaemia. Nat. Commun. 2016, 7, 11790. [CrossRef]

96. Gu, Z.; Churchman, M.; Roberts, K.; Li, Y.; Liu, Y.; Harvey, R.C.; Mccastlain, K.; Reshmi, S.C.; Payne-turner, D.; Iacobucci, I.; et al. Genomic analyses identify recurrent MEF2D fusions in acute lymphoblastic leukaemia. Nat. Commun. 2016, 7, 13331. [CrossRef]

97. Ferrando, A.A.; Neuberg, D.S.; Staunton, J.; Loh, M.L.; Huard, C.; Raimondi, S.C.; Behm, F.G.; Pui, C.H.; Downing, J.R.; Gilliland, D.G.; et al. Gene expression signatures define novel oncogenic pathways in T cell acute lymphoblastic leukemia. Cancer Cell 2002, 1, 75-87. [CrossRef]

98. Farrar, J.E.; Schuback, H.L.; Ries, R.E.; Wai, D.; Hampton, O.A.; Trevino, L.R.; Alonzo, T.A.; Auvil, J.M.G.; Davidsen, T.M.; Gesuwan, P.; et al. Genomic profiling of pediatric acute myeloid leukemia reveals a changing mutational landscape from disease diagnosis to relapse. Cancer Res. 2016, 76, 2197-2205. [CrossRef]

99. Stieglitz, E.; Taylor-Weiner, A.N.; Chang, T.Y.; Gelston, L.C.; Wang, Y.D.; Mazor, T.; Esquivel, E.; Yu, A.; Seepo, S.; Olsen, S.R.; et al. The genomic landscape of juvenile myelomonocytic leukemia. Nat. Genet. 2015, 47, 1326-1333. [CrossRef]

100. Okabe, S.; Tauchi, T.; Tanaka, Y.; Ohyashiki, K. Therapeutic targeting of Aurora A kinase in Philadelphia chromosome-positive ABL tyrosine kinase inhibitor-resistant cells. Oncotarget 2018, 9, 32496-32506. [CrossRef]

101. Eldfors, S.; Kuusanmäki, H.; Kontro, M.; Majumder, M.M.; Parsons, A.; Edgren, H.; Pemovska, T.; Kallioniemi, O.; Wennerberg, K. Idelalisib sensitivity and mechanisms of disease progression in relapsed TCF3-PBX1 acute lymphoblastic leukemia. Leukemia 2017, 31, 51-57. [CrossRef]

102. Fischer, U.; Forster, M.; Rinaldi, A.; Risch, T.; Sungalee, S.; Warnatz, H.-J.; Bornhauser, B.; Gombert, M.; Kratsch, C. Genomics and drug profiling of fatal TCF3-HLF-positive acute lymphoblastic leukemia identifies recurrent mutation patterns and therapeutic options. Nat. Genet. 2015, 47, 1020-1029. [CrossRef]

103. Janczar, S.; Janczar, K.; Pastorczak, A.; Harb, H.; Paige, A.J.W.; Zalewska-Szewczyk, B.; Danilewicz, M.; Mlynarski, W. The role of histone protein modifications and mutations in histone modifiers in pediatric B-cell progenitor acute lymphoblastic leukemia. Cancers 2017, 9, 2. [CrossRef]

104. Griffith, M.; Griffith, O.L.; Krysiak, K.; Skidmore, Z.L.; Campbell, K.M.; Lesurf, R.; Hundal, J.; Zhang, J.; Spies, N.C.; Ainscough, B.J.; et al. Comprehensive genomic analysis reveals FLT3 activation and a therapeutic strategy for a patient with relapsed adult B-lymphoblastic leukemia. Exp. Hematol. 2016, 44, 603-613. [CrossRef]

105. Moriyama, T.; Liu, S.; Li, J.; Meyer, J.; Zhao, X.; Yang, W.; Shao, Y.; Heath, R.; Carroll, W.L. Mechanisms of NT5C2-Mediated Thiopurine Resistance in Acute Lymphoblastic Leukemia. Mol. Cancer Ther. 2019, 18, 1887-1895. [CrossRef]

106. Mullighan, C.; Zhang, J.; Kasper, L.; Lerach, S.; Payne-Turner, D.; Phillips, L.; Heatley, S.; Holmfeldt, L.; Collins-Underwood, J.; Ma, J.; et al. CREBBP mutations in relapsed acute lymphoblastic leukaemia. Nature 2011, 471, 235-241. [CrossRef]

107. Diaz-Flores, E.; Comeaux, E.Q.; Kim, K.L.; Melnik, E.; Beckman, K.; Davis, K.L.; Wu, K.; Akutagawa, J.; Bridges, O.; Marino, R.; et al. Bcl-2 Is a Therapeutic Target for Hypodiploid B-Lineage Acute Lymphoblastic Leukemia. Cancer Res. 2019, 79, $2339-2351$. [CrossRef]

108. Harrison, C.J.; Moorman, A.V.; Schwab, C.; Carroll, A.J.; Raetz, E.A.; Devidas, M.; Strehl, S.; Nebral, K.; Harbott, J. An international study of intrachromosomal amplification of chromosome 21 (iAMP21): Cytogenetic characterization and outcome. Leukemia 2014, 28, 1015-1021. [CrossRef]

109. Habets, R.A.; De Bock, C.E.; Serneels, L.; Lodewijckx, I.; Verbeke, D.; Nittner, D.; Narlawar, R.; Demeyer, S.; Dooley, J. Safe targeting of T cell acute lymphoblastic leukemia by pathology-specific NOTCH inhibition. Sci. Transl. Med. 2019, 11, eaau6246. [CrossRef]

110. Marke, R.; van Leeuwen, F.N.; Scheijen, B. The many faces of IKZF1 in B-cell precursor acute lymphoblastic leukemia. Haematologica 2018, 103, 565-574. [CrossRef] 
111. Sakaguchi, K.; Imamura, T.; Ishimaru, S.; Imai, C.; Shimonodan, H.; Fujita, N.; Okada, K.; Taketani, T.; Kanai, R.; Tauchi, H.; et al. Nationwide study of pediatric B-cell precursor acute lymphoblastic leukemia with chromosome 8q24/MYC rearrangement in Japan. Pediatr. Blood Cancer 2020, 67, e28341. [CrossRef]

112. Deenik, W.; Beverloo, H.B.; van der Poel-van de Luytgaarde, S.C.P.A.M.; Wattel, M.M.; van Esser, J.W.J.; Valk, P.J.M.; Cornelissen, J.J. Rapid complete cytogenetic remission after upfront dasatinib monotherapy in a patient with a NUP214-ABL1-positive T-cell acute lymphoblastic leukemia. Leukemia 2009, 23, 627-629. [CrossRef]

113. Van Vlierberghe, P.; Ferrando, A. The molecular basis of T cell acute lymphoblastic leukemia. J. Clin. Investig. 2012, 122, 3398-3406. [CrossRef]

114. Carrasco Salas, P.; Fernández, L.; Vela, M.; Bueno, D.; González, B.; Valentín, J.; Lapunzina, P.; Pérez-Martínez, A. The role of CDKN2A/B deletions in pediatric acute lymphoblastic leukemia. Pediatr. Hematol. Oncol. 2016, 33, 415-422. [CrossRef]

115. Rubnitz, J.E.; Camitta, B.M.; Mahmoud, H.; Raimondi, S.C.; Carroll, A.J.; Borowitz, M.J.; Shuster, J.J.; Link, M.P.; Pullen, D.J.; Downing, J.R.; et al. Childhood Acute Lymphoblastic Leukemia With the MLL-ENL Fusion and t(11;19)(q23;p13.3) Translocation. J. Clin. Oncol. 2019, 17, 191-196. [CrossRef]

116. Tran, T.H.; Loh, M.L. Ph-like acute lymphoblastic leukemia. Hematology 2016, 1, 561-566. [CrossRef]

117. Tasian, S.K.; Loh, M.L.; Hunger, S.P. Philadelphia chromosome-like acute lymphoblastic leukemia. Blood 2017, 130, $2064-2072$. [CrossRef]

118. Stein, E.M.; Garcia-Manero, G.; Rizzieri, D.A.; Tibes, R.; Berdeja, J.G.; Savona, M.R.; Jongen-lavrenic, M.; Altman, J.K.; Thomson, B.; Blakemore, S.J.; et al. The DOT1L inhibitor pinometostat reduces H3K79 methylation and has modest clinical activity in adult acute leukemia. Blood 2018, 131, 2661-2669. [CrossRef]

119. Schmoellerl, J.; Barbosa, I.; Eder, T.; Brandstoetter, T.; Schmidt, L.; Maurer, B.; Troester, S. CDK6 is an essential direct target of NUP98-fusion proteins in acute myeloid leukemia. Blood 2020, 136, 387-400. [CrossRef]

120. Kivioja, J.L.; Thanasopoulou, A.; Kumar, A.; Kontro, M.; Yadav, B.; Heckman, C.A. Dasatinib and navitoclax act synergistically to target NUP98-NSD1+/FLT3-ITD+ acute myeloid leukemia. Leukemia 2019, 33, 1360-1372. [CrossRef]

121. Paschka, P.; Schlenk, R.F.; Weber, D.; Benner, A.; Bullinger, L.; Heuser, M.; Gaidzik, V.I.; Thol, F.; Agrawal, M.; Teleanu, V.; et al. Adding dasatinib to intensive treatment in core-binding factor acute myeloid leukemia-results of the AMLSG 11-08 trial. Leukemia 2018, 32, 1621-1630. [CrossRef]

122. Stein, E.M.; DiNardo, C.D.; Fathi, A.T.; Pollyea, D.A.; Stone, R.M.; Altman, J.K.; Roboz, G.J.; Patel, M.R.; Collins, R.; Flinn, I.W.; et al. Molecular remission and response patterns in patients with mutant-IDH2 acute myeloid leukemia treated with enasidenib. Blood 2019, 133, 676-687. [CrossRef]

123. Cucchi, D.G.J.; Bachas, C.; van den Heuvel-Eibrink, M.M.; Arentsen-Peters, S.T.C.J.M.; Kwidama, Z.J.; Schuurhuis, G.J.; Assaraf, Y.G.; de Haas, V.; Kaspers, G.J.L.; Cloos, J. Harnessing gene expression profiles for the identification of ex vivo drug response genes in pediatric acute myeloid leukemia. Cancers 2020, 12, 1247. [CrossRef]

124. Candelli, T.; Schneider, P.; Castro, P.G.; Jones, L.A.; Bodewes, E.; Rockx-Brouwer, D.; Pieters, R.; Holstege, F.C.P.; Margaritis, T.; Stam, R.W. Acute lymphoblastic leukemia Identification and characterization of relapse-initiating cells in MLL-rearranged infant ALL by single-cell transcriptomics. Leukemia 2021. [CrossRef]

125. Ma, X.; Edmonson, M.; Yergeau, D.; Muzny, D.M.; Hampton, O.A.; Rusch, M.; Song, G.; Easton, J.; Harvey, R.C.; Wheeler, D.A.; et al. Rise and fall of subclones from diagnosis to relapse in pediatric B-acute lymphoblastic leukaemia. Nat. Commun. 2015, 6, 6604. [CrossRef]

126. Dobson, S.M.; García-Prat, L.; Vanner, R.J.; Wintersinger, J.; Waanders, E.; Gu, Z.; McLeod, J.; Gan, O.I.; Grandal, I.; Payne-Turner, D.; et al. Relapse-fated latent diagnosis subclones in acute B lineage leukemia are drug tolerant and possess distinct metabolic programs. Cancer Discov. 2020, 10, 568-587. [CrossRef]

127. Zuna, J.; Cavé, H.; Eckert, C.; Szczepanski, T.; Meyer, C.; Mejstrikova, E.; Fronkova, E.; Muzikova, K.; Clappier, E.; Mendelova, D.; et al. Childhood secondary ALL after ALL treatment. Leukemia 2007, 21, 1431-1435. [CrossRef]

128. Alpár, D.; Nagy, G.; Hohoff, C.; Kajtár, B.; Bartyik, K.; Hermesz, J.; Jáksó, P.; Andrikovics, H.; Kereskai, L.; Pajor, L. Sex chromosome changes after sex-mismatched allogeneic bone marrow transplantation can mislead the chimerism analysis. Pediatr. Blood Cancer 2010, 55, 1239-1242. [CrossRef]

129. Rabilloud, T.; Potier, D.; Pankaew, S.; Nozais, M.; Loosveld, M.; Payet-Bornet, D. Single-cell profiling identifies pre-existing CD19-negative subclones in a B-ALL patient with CD19-negative relapse after CAR-T therapy. Nat. Commun. 2021, $12,865$. [CrossRef]

130. Zhao, Y.; Aldoss, I.; Qu, C.; Crawford, J.C.; Gu, Z.; Allen, E.K.; Zamora, A.E.; Alexander, T.B.; Wang, J.; Goto, H.; et al. Tumorintrinsic and -extrinsic determinants of response to blinatumomab in adults with B-ALL. Blood 2021, 137, 471-484. [CrossRef]

131. Ratti, S.; Lonetti, A.; Follo, M.Y.; Paganelli, F.; Martelli, A.M.; Chiarini, F.; Evangelisti, C. B-all complexity: Is targeted therapy still a valuable approach for pediatric patients? Cancers 2020, 12, 3498. [CrossRef]

132. Jeha, S.; Choi, J.; Roberts, K.G.; Pei, D.; Coustan-Smith, E.; Inaba, H.; Rubnitz, J.E.; Ribeiro, R.C.; Gruber, T.A.; Raimondi, S.C.; et al. Clinical significance of novel subtypes of acute lymphoblastic leukemia in the context of minimal residual disease-directed therapy. Blood Cancer Discov. 2021, 2, 326-337. [CrossRef]

133. Guryanova, O.A.; Shank, K.; Spitzer, B.; Luciani, L.; Koche, R.P.; Garrett-Bakelman, F.E.; Ganzel, C.; Durham, B.H.; Mohanty, A.; Hoermann, G.; et al. DNMT3A mutations promote anthracycline resistance in acute myeloid leukemia via impaired nucleosome remodeling. Nat. Med. 2016, 22, 1488-1495. [CrossRef] 
134. Wang, R.; Dang, M.; Harada, K.; Han, G.; Wang, F.; Pool Pizzi, M.; Zhao, M.; Tatlonghari, G.; Zhang, S.; Hao, D.; et al. Single-cell dissection of intratumoral heterogeneity and lineage diversity in metastatic gastric adenocarcinoma. Nat. Med. 2021, 27, 141-151. [CrossRef]

135. Karaayvaz, M.; Cristea, S.; Gillespie, S.M.; Patel, A.P.; Mylvaganam, R.; Luo, C.C.; Specht, M.C.; Bernstein, B.E.; Michor, F.; Ellisen, L.W. Unravelling subclonal heterogeneity and aggressive disease states in TNBC through single-cell RNA-seq. Nat. Commun. 2018, 9, 3588. [CrossRef]

136. Jerchel, I.S.; Hoogkamer, A.Q.; Ariës, I.M.; Steeghs, E.M.P.; Boer, J.M.; Besselink, N.J.M.; Boeree, A.; Van De Ven, C.; De GrootKruseman, H.A.; De Haas, V.; et al. RAS pathway mutations as a predictive biomarker for treatment adaptation in pediatric B-cell precursor acute lymphoblastic leukemia. Leukemia 2018, 32, 931-940. [CrossRef]

137. Antić, Ž.; Yu, J.; Van Reijmersdal, S.V.; Van Dijk, A.; Dekker, L.; Segerink, W.H.; Sonneveld, E.; Fiocco, M.; Pieters, R.; Hoogerbrugge, P.M.; et al. Multiclonal complexity of pediatric acute lymphoblastic leukemia and the prognostic relevance of subclonal mutations. Haematologica 2020. [CrossRef]

138. Barz, M.J.; Hof, J.; Groeneveld-Krentz, S.; Loh, J.W.; Szymansky, A.; Astrahantseff, K.; von Stackelberg, A.; Khiabanian, H.; Ferrando, A.A.; Eckert, C.; et al. Subclonal NT5C2 mutations are associated with poor outcomes after relapse of pediatric acute lymphoblastic leukemia. Blood 2020, 135, 921-933. [CrossRef]

139. U.S. National Library of Medicine ClinicalTrials. Available online: https:/ / clinicaltrials.gov (accessed on 9 July 2021).

140. Jeha, S.; Coustan-Smith, E.; Pei, D.; Sandlund, J.T.; Rubnitz, J.E.; Howard, S.C.; Inaba, H.; Bhojwani, D.; Metzger, M.L.; Cheng, C.; et al. Impact of tyrosine kinase inhibitors on minimal residual disease and outcome in childhood Philadelphia chromosomepositive acute lymphoblastic leukemia. Cancer 2014, 120, 1514-1519. [CrossRef]

141. Porkka, K.; Koskenvesa, P.; Lundán, T.; Rimpiläinen, J.; Mustjoki, S.; Smykla, R.; Wild, R.; Luo, R.; Arnan, M.; Brethon, B.; et al. Dasatinib crosses the blood-brain barrier and is an efficient therapy for central nervous system Philadelphia chromosome-positive leukemia. Blood 2008, 112, 1005-1012. [CrossRef]

142. Zwaan, C.M.; Söderhäll, S.; Brethon, B.; Luciani, M.; Rizzari, C.; Stam, R.W.; Besse, E.; Dutreix, C.; Fagioli, F.; Ho, P.A.; et al. A phase 1/2, open-label, dose-escalation study of midostaurin in children with relapsed or refractory acute leukaemia. Br. J. Haematol. 2019, 185, 623-627. [CrossRef]

143. Karol, S.E.; Alexander, T.; Das Gupta, S.; Pounds, S.B.; Canavera, K.; Klco, J.M.; Lacayo, N.J.; Pui, C.-H.; Opferman, J.T.; Rubnitz, J.E. Safety and activity of venetoclax in combination with high-dose cytarabine in children with relapsed or refractory acute myeloid leukemia. J. Clin. Oncol. 2019, 37, 10004. [CrossRef]

144. Lonetti, A.; Pession, A.; Masetti, R. Targeted Therapies for Pediatric AML: Gaps and Perspective. Front. Pediatr. 2019,7 , 463. [CrossRef]

145. DiNardo, C.; Stein, E.; de Botton, S.; Roboz, G.; Altman, J.; Mims, A.; Swords, R.; Collins, R.; Mannis, G.; DA, P.; et al. Durable Remissions with Ivosidenib in IDH1-Mutated Relapsed or Refractory AML. N. Engl. J. Med. 2018, 378, 2386-2398. [CrossRef]

146. Zhao, J.; Song, Y.; Liu, D. Gilteritinib: A novel FLT3 inhibitor for acute myeloid leukemia. Biomark. Res. 2019, 7, 19. [CrossRef]

147. Dai, H.P.; Yin, J.; Li, Z.; Yang, C.X.; Cao, T.; Chen, P.; Zong, Y.H.; Zhu, M.Q.; Zhu, X.M.; Xiao, S.; et al. Rapid Molecular Response to Dasatinib in a Pediatric Relapsed Acute Lymphoblastic Leukemia With NCOR1-LYN Fusion. Front. Oncol. 2020, 10, 359. [CrossRef]

148. Worst, B.C.; van Tilburg, C.M.; Balasubramanian, G.P.; Fiesel, P.; Witt, R.; Freitag, A.; Boudalil, M.; Previti, C.; Wolf, S.; Schmidt, S.; et al. Next-generation personalised medicine for high-risk paediatric cancer patients-The INFORM pilot study. Eur. J. Cancer 2016, 65, 91-101. [CrossRef]

149. Pikman, Y.; Tasian, S.K.; Sulis, M.L.; Stevenson, K.; Blonquist, T.M.; Apsel Winger, B.; Cooper, T.M.; Pauly, M.; Maloney, K.W.; Burke, M.J.; et al. Matched Targeted Therapy for Pediatric Patients with Relapsed, Refractory, or High-Risk Leukemias: A Report from the LEAP Consortium. Cancer Discov. 2021, 11, 1424-1439. [CrossRef]

150. Marks, L.J.; Oberg, J.A.; Pendrick, D.; Sireci, A.N.; Glasser, C.; Coval, C.; Zylber, R.J.; Chung, W.K.; Pang, J.; Turk, A.T.; et al. Precision medicine in children and young adults with hematologic malignancies and blood disorders: The Columbia university experience. Front. Pediatr. 2017, 5, 265. [CrossRef]

151. Khater, F.; Vairy, S.; Langlois, S.; Dumoucel, S.; Sontag, T.; St-Onge, P.; Bittencourt, H.; Dal Soglio, D.; Champagne, J.; Duval, M.; et al. Molecular Profiling of Hard-to-Treat Childhood and Adolescent Cancers. JAMA Netw. Open 2019, 2, e192906. [CrossRef]

152. Barahona, P.; Fletcher, J.; Fuentes-Bolanos, N.; Gauthier, M.-E.; Haber, M.; Lock, R.B.; Marshall, G.M.; Mayoh, C.; Mould, E.; Nagabushan, S.; et al. Zero Childhood Cancer (ZERO): A comprehensive precision medicine platform for children with high-risk cancer. In Proceedings of the Cancer Research; American Association for Cancer Research (AACR), Los Angeles, CA, USA, 24-29 April 2020; Volume 80, p. A52.

153. Mody, R.J.; Wu, Y.M.; Lonigro, R.J.; Cao, X.; Roychowdhury, S.; Vats, P.; Frank, K.M.; Prensner, J.R.; Asangani, I.; Palanisamy, $\mathrm{N}$; et al. Integrative clinical sequencing in the management of refractory or relapsed cancer in youth. JAMA-J. Am. Med. Assoc. 2015, 314, 913-925. [CrossRef]

154. Harris, M.H.; DuBois, S.G.; Bender, J.L.G.; Kim, A.; Crompton, B.D.; Parker, E.; Dumont, I.P.; Hong, A.L.; Guo, D.; Church, A.; et al. Multicenter feasibility study of tumor molecular profiling to inform therapeutic decisions in advanced pediatric solid tumors. JAMA Oncol. 2016, 2, 608-615. [CrossRef] 
155. McFarland, J.M.; Paolella, B.R.; Warren, A.; Geiger-Schuller, K.; Shibue, T.; Rothberg, M.; Kuksenko, O.; Colgan, W.N.; Jones, A.; Chambers, E.; et al. Multiplexed single-cell transcriptional response profiling to define cancer vulnerabilities and therapeutic mechanism of action. Nat. Commun. 2020, 11, 4296. [CrossRef]

156. Bartram, J.; Goulden, N.; Wright, G.; Adams, S.; Brooks, T.; Edwards, D.; Inglott, S.; Yousafzai, Y.; Hubank, M.; Halsey, C. High throughput sequencing in acute lymphoblastic leukemia reveals clonal architecture of central nervous system and bone marrow compartments. Haematologica 2018, 103, e110-e114. [CrossRef] [PubMed]

157. Gocho, Y.; Liu, J.; Hu, J.; Yang, W.; Dharia, N.V.; Zhang, J.; Shi, H.; Du, G.; John, A.; Lin, T.N.; et al. Network-based systems pharmacology reveals heterogeneity in LCK and BCL2 signaling and therapeutic sensitivity of T-cell acute lymphoblastic leukemia. Nat. Cancer 2021, 2, 284-299. [CrossRef]

158. Xiao, W.; Miles, L.A.; Bowman, R.L.; Durani, V.; Tian, H.S.; DelGaudio, N.L.; Mishra, T.; Zhu, M.; Zhang, Y.; Stump, S.E.; et al. A JAK2/IDH1-mutant MPN clone unmasked by ivosidenib in an AML patient without antecedent MPN. Blood Adv. 2020, 4, 6034-6038. [CrossRef]

159. McKenney, A.S.; Lau, A.N.; Hanasoge Somasundara, A.V.; Spitzer, B.; Intlekofer, A.M.; Ahn, J.; Shank, K.; Rapaport, F.T.; Patel, M.A.; Papalexi, E.; et al. JAK2/IDH-mutant-driven myeloproliferative neoplasm is sensitive to combined targeted inhibition. J. Clin. Investig. 2018, 128, 789-804. [CrossRef]

160. NCT05014165. Available online: https:/ / clinicaltrials.gov/ct2/show /NCT05014165 (accessed on 4 November 2021).

161. NCT03117751. Available online: https:/ / clinicaltrials.gov/ct2/show / NCT03117751 (accessed on 4 November 2021).

162. Zeng, T.; Dai, H. Single-cell RNA sequencing-based computational analysis to describe disease heterogeneity. Front. Genet. 2019, 10, 629. [CrossRef]

163. Maley, C.C.; Aktipis, A.; Graham, T.A.; Sottoriva, A.; Boddy, A.M.; Janiszewska, M.; Silva, A.S.; Gerlinger, M.; Yuan, Y.; Pienta, K.J.; et al. Classifying the evolutionary and ecological features of neoplasms. Nat. Rev. Cancer 2017, 17, 605-619. [CrossRef] 